\title{
Rivers and streams in the media: a content analysis of ecosystem services
}

\author{
Matthew A. Weber $^{1}, \underline{\text { Shannon Caplan }}^{2}, \underline{\text { Paul Ringold }}^{3}$ and Karen Blocksom ${ }^{4}$
}

\begin{abstract}
Although ecosystem services research has become common, few efforts are directed toward in-depth understanding of the specific ecological quantities people value. The theoretical framework of final ecosystem services focuses attention on such measurable attributes, as a common currency for social-ecological systems research. Environmental communications as well as ecological monitoring and analysis efforts could be enhanced through increased documentation of final ecosystem services. For example, small changes in the way ecosystems are described could strongly influence relevance to the public and improve the foundation for environmental decision making. Focusing on rivers and streams, we conducted a content analysis of existing publications to document the breadth and frequency with which various measurable attributes, such as flooding, water quality characteristics, and wildlife appeared in different news sources over a multiyear timeline. In addition to attributes, motivations for human interest in river-related resources were also coded, such as recreation or preservation for future generations. To allow testing of differences between materials written for different audiences, three sources were sampled: a blog hosted by National Geographic, New York Times articles, and Wall Street Journal articles. The coding approach was rigorously tested in a pilot phase, with measures developed to ensure high data quality, including use of two independent coders. Results show numerous similarities across sources with some notable differences in emphasis. Significant relationships between groups of attribute and motivation codes were also found, one outcome of which is further support for the importance of nonuse values for fish and wildlife. Besides offering insight on ecosystem services, the project demonstrates an in-depth quantitative approach to analyzing preexisting qualitative data.
\end{abstract}

Key Words: content analysis; final ecosystem services; media; multivariate analysis of variance; nonmetric multidimensional scaling; rivers and streams

\section{INTRODUCTION}

Ecosystem services is an interdisciplinary field examining the relationship between human welfare and environmental management. In recent years, the field has exploded from a niche literature into an organizing principle for research and management, influencing institutions such as university departments and government agencies. However, in some cases the terminology is overused such that the original intent to address a "lack of appreciation of societal dependence on natural ecosystems" (Daily 1997:xv) has been obscured. Although numerous studies self-identify as ecosystem services investigations, they do not always clearly link to human welfare.

The perspective of "final" ecosystem services can be seen as a means of refocusing environmental study on direct links to human health and well-being. Final services are select, valued endpoints of ecological production functions (Boyd and Banzhaf 2007, Ringold et al. 2009, 2013, Boyd and Krupnick 2013, Landers and Nahlik 2013, Boyd et al. 2016). A point to be stressed is that final services rely on extraordinarily important intermediate ecosystem functions and processes. The final model is not the only way to structure an ecosystem services inquiry, but it does carry the advantage of promoting attention on measurable environmental quantities of direct interest to the public, while preserving the role of underlying ecological complexity. Final services, once identified, may then serve as the variables for communicating environmental condition, or judging trade-offs between environmental outcomes in a form transparent for public review.

It should be noted that there is active debate regarding ecosystem services frameworks. In particular, the final services approach on measurable quantities differs from categorizing ecosystem services as provisioning, supporting, regulating, and cultural, as adopted by the Millennium Ecosystem Assessment (2005). Although we recognize differences in approach, we also assert that the goal of identifying natural resources that people care about is a broad arena that transcends the debate. A goal similar to ours occurs whenever investigators seek to directly link environmental measurements with human value, a common aspiration occurring under various names. For example, Keeler et al. (2012:18260) discussed an ecosystem services framework linking environmental changes "to changes in the provision of ecosystem goods and services that directly affect human wellbeing;" Wainger and Mazzotta (2011:712) described a similar ecosystem services framework hinging on "outcomes that matter to people," and Haines-Young and Potschin (2010) framed ecosystem services as a cascade starting with biophysical processes and ultimately yielding human value via final products. It isn't even necessary to use ecosystem services terminology. Schiller et al. (2001) described publicly relevant commonlanguage indicators, and Braden et al. (2015:450) discussed the need to "systematically collect data at interfaces linking humans to the natural environment" in the context of sustainability. Scientists need not invoke specialized terms to take part in research describing the relationship between humans and nature. Likewise, people don't need to be familiar with scientific jargon to appreciate the natural world. Studies have shown that people ascribe importance to the environment, despite unfamiliarity with the ecosystem services phrase (Böck et al. 2015, Nature Conservancy 2010).

With a perspective on final services, linking data, or any other similar term, the key question soon becomes: what are these select environmental attributes? Multiple original data methods can be

${ }^{1}$ Independent Consultant, ${ }^{2}$ Department of Anthropology, Oregon State University, ${ }^{3}$ U.S. Environmental Protection Agency, Office of Research and Development, Western Ecology Division, ${ }^{4}$ U.S. Environmental Protection Agency, Western Ecology Division 
used to identify them, such as expert opinion (Ringold et al. 2009, 2013), focus groups and/or semistructured interviews with laypersons (Weber and Ringold 2015), and survey research. Our investigation takes a different tack, relying instead on the vast arena of text available online.

To extract information from sampled texts, we used content analysis, a commonly used quantitative method to analyze qualitative data (Bernard 2011). Content analysis of secondary sources is increasingly common in natural resource management in which primary data may be cost prohibitive or incomparable across regions or time (Houston et al. 2010:392). Examples include media representations of human-wildlife conflict (e.g., Siemer et al. 2007, Muter et al. 2009, Houston et al. 2010, Alexander and Quinn 2011, Alessi et al. 2013), environmental risks or issues (e.g., Gunter and Harris 1998, Brossard et al. 2004, Gunter 2005, Tilt and Xiao 2010, Lopera and Moreno 2014, Nelson et al. 2014), and management and planning (Proctor 1998, Bengston et al. 2004, Norton 2008).

Our study builds on previous research directly engaging diverse members of the public (Weber and Ringold 2015; see also http:// conference.ifas.ufl.edu/aces 14/posters/Weber, $\% 20$ Matthew $\% 20-\%$ 20Oregon FEGS Poster corrected.pdf). A valuable outcome of this prior work was a provisional codebook organizing the breadth of river and stream attributes and associated motivations for valuing them as manifest in layperson narratives. Whereas statistical analysis of transcripts is limited because of issues such as "groupthink" (Janis 1972), content analysis on a random sample of individual texts allows relatively straightforward hypothesis testing. Taken together, the chain of research comprises a classic mixed methods sequence having a preliminary exploratory phase to develop hypotheses, with follow-up statistical testing (Creswell 2014). Specifically, we address three topics: (1) Document the range and relative frequency of attributes and motivations used in texts to represent stream ecosystems and human interest in them; (2) Test whether attributes and motivations vary by publication source or date, and; (3) Test associations between defined categories of attributes and motivations.

\section{METHODS}

\section{Sampling}

Strategic sampling was a challenging aspect of the study. Overall, we wanted to compare and contrast different "voices" on rivers and streams, at a minimum, environmentalist perspectives vs. mainstream media. While drawing from different sources, we also wanted to control for the influence of time by using a consistent sampling window because newsworthy river-related phenomena can be episodic, e.g., flooding. An additional factor affecting sampling was that we found significant resources were needed to extract the information we sought in a reliable manner from a given article. This meant that we could not set a final sample size at the outset, but rather had to plan adaptively according to how quickly available project resources were used.

For environmentalist texts, we decided to analyze the National Geographic blog, Water Currents (http://voices.nationalgeographic. com/blog/water-currents/). Although not blatantly environmentalist, the National Geographic Society mission statement includes a reference to helping protect the diverse creatures that share our world, which stands out from the organizing principles of mainstream news sources. Blog contributors are affiliated with groups such as National Geographic itself, National Geographic's Freshwater Initiative, and the Environmental Defense Fund. The blog is hosted by Sandra Postel, Freshwater Fellow with National Geographic and Director and Founder of the Global Water Policy Project. Blog content is almost exclusively devoted to rivers and streams. Blog articles were manually filtered to include only those dealing with domestic U.S. rivers and to exclude articles with only a passing reference to rivers and streams (defined as two or fewer paragraphs within an article). Initially, we had intended to census sample the blog; however, due to a high effort needed to code numerous concepts reliably, we did not have the capacity to sample the most recent posts, and the sample frame was restricted to November 11, 2009 (the date of the first post) to February 15, 2012, which included 28 blog posts. This interval became the boundaries for the sampling window applied to other sources.

In determining a mainstream news source, we sought something with high circulation and accessible indexing. The New York Times (NYT) and the Wall Street Journal (WSJ) have consistently high rankings for daily print and digital circulation and are both available through an online database (ProQuest 2017). Candidate content from NYT was determined through querying for subject index terms "rivers" and "creeks and streams." Content was considered acceptable if it contained at least some discussion of U.S. rivers and/or streams. Within the sampling window there were 71 articles meeting our criteria, of which 40 were randomly selected for analysis.

After preliminary statistical analysis, we found significantly diminished influence on relative code frequencies from the last few blog and NYT articles analyzed. We thus decided to include several WSJ articles as a third source. This allowed us to explore whether the WSJ's reputation as a conservative, business-interest periodical would show a dramatic contrast with other sources. Given the small sample size planned for WSJ, we used a slightly different sampling approach, stratifying across years 2010 and 2011 (instead of the full sample interval used for the blog and the NYT) to maintain the ability to test the influence of time. There were 52 articles meeting sampling criteria, of which 8 were randomly selected for analysis.

\section{Coding}

The codebook is hierarchical with two main categories: physical attributes of rivers and streams, and motivations for interest in rivers and streams. Attributes are further divided into water, fish, wildlife, vegetation, channel, and human. Note in particular the last category: not all measurable attributes of streams are ecological, and we purposefully included human attributes to allow the contrasting of the incidence of ecological features vs. human modifications. Motivations are divided into consumptive use, nonconsumptive use, and not use contingent. These categories facilitate distinguishing the traditional extractive uses from the recreational and ecological motivations, and parallel the components of "total economic value" (Millennium Ecosystem Assessment 2005, National Research Council 2004:46). The not use contingent category is important for representing so-called nonuse values. For example, people may value the existence of a 
species or natural area without the necessity of actually seeing or otherwise using those resources (e.g., Krutilla 1976, Freeman 2003, Johnston et al. 2003). Codes are applied at most once per paragraph, although we expected that multiple different codes would occur within a given paragraph, with repeated codes possible for different paragraphs within a single article.

An important distinction between various content analysis methodologies is the use of human coders vs. automated approaches. Each method carries trade-offs, with efficacy of computer aids varying by project (Krippendorff 2013). A general limitation of automated coding is that it requires the researcher to anticipate how concepts will be presented in texts, whereas human coding does not require such omniscience. Some research questions, such as occurrences of given keywords, are easily automated. Specialized software is also available for more detailed questions, for example Bengston et al. (2004) studied the longitudinal frequency of three forest value orientations in national newspapers using automated paragraph scoring based on preprogrammed word combinations. Our content analysis study is unusual in that the coding schema is complex. The codebook was designed and vetted to include a mechanism to code essentially every measurable feature of rivers and streams as well as every encountered motivation. Furthermore, each code can be expressed multiple ways. For example, concern over "water contact health risk" could be stated in a variety of word combinations. Accordingly, we ascertained that the effort needed to tailor and test an algorithm specific to our study, although theoretically possible, would not be feasible within our budget and timeline. This limited us to a smaller sample size than typical for an automated study, but with a trade-off of richly coded data.

Two student coders were used, allowing meaning to emerge from texts without subconscious coding biases of the principal investigators (Neuendorf 2002). A pilot phase was a crucial element of the study, particularly for coders to practice abstracting from their own reactions and instead cueing to author intent. Several refinements to the provisional codebook occurred during the pilot phase, mainly adjusting coding rules to encourage reliable coding, but also the consolidation of some codes and the emergence of a few new themes. The final codebook contains 54 codes total, including NOCODE, denoting no attribute or motivation codes applied to a paragraph.

Initially, we hoped each coder would code separate texts to increase the sample of analyzed articles, but during the pilot stage, intercoder reliability (Fleiss' Kappa; Fleiss 1971, Krippendorff 2013) for many codes indicated a need for additional consistency checks. Although some of our codes were relatively unambiguous (e.g., BRD for any reference to birds), several motivation codes required interpretation of nuance. For example, our code "supposed to be" (SUPP) necessitated that a paragraph contains a judgment regarding a preferred "natural" state. There also arose passages that were ambiguously written even for coding rules that seemed deterministic. We could have dropped the codes that tended not to meet minimum the intercoder reliability statistics, yet loss of data richness would sacrifice our study objectives of providing a comprehensive view of recurring attributes and motivations manifest in texts. We thus developed a redundancy coding and resolution strategy to maximize the quality of information extracted. In team-based qualitative research, collaborators often discuss disagreements until consensus is reached (e.g., Gerbert et al. 1999, Mackey et al. 2004). However, redundant coding and reconciliation procedures appear to be rare in content analysis. In the first step of our redundant coding design, coders independently coded content for a group of articles and then relayed their work to a principal investigator. The principal investigator then merged the two files for agreement analysis, a process facilitated by the "Coding Analysis Toolkit" (Shulman 2017). A list of coding disagreements was thereby generated and sent back to coders for their independent review because we wanted our coders to maintain autonomy throughout the reconciliation process. Coder revisions were then merged and again checked for agreement. In instances in which coders still did not agree, the principal investigators made a decision, thereby generating a final coded article. Paragraphs without attribute or motivation codes were labeled NOCODE retroactively to allow the total number of paragraphs to be represented in the final analysis. Coding was conducted using ATLAS.ti software (Scientific Software Development 2015).

\section{Visualization and statistical analyses}

Data generated by coding were reformatted and reduced to conduct analyses inaccessible to a solely qualitative approach (Riffe et al. 2014). Code counts per article were normalized by the number of paragraphs to control for article length. The year of each article was also coded, as well as the season (spring: March to May; summer, June to Aug.; fall, Sept. to Nov.; winter, Dec. to Feb.). To document frequencies of attributes and motivations manifested in source texts, we utilized simple descriptive statistics expressed in bar charts and box plots. To investigate the influence of article source, publication year, and publication season on normalized code frequencies, we conducted a series of nonparametric multivariate analyses of variance (MANOVA) tests (Anderson 2001). As an added data visualization aid for interpreting MANOVA results, we used nonmetric multidimensional scaling (NMS) plots (Andsager and Powers 1999, McCune and Grace 2002). Separate two-dimensional NMS plots were planned for attribute and motivation code frequencies, with each article providing a datapoint on each plot. Plot axes are correlated with codes that account for the greatest combined difference between articles in terms of code frequencies. This technique is especially useful for visualizing clusters of similar datapoints and has been used in ecology to discern similar species distributions for various field sites (Clarke 1993). There may be as many vectors as there are variables, with vector length being a measure of that code's importance in accounting for differences between datapoints.

Tests of association between attributes and motivations were conducted at the paragraph level to make use of finer data resolution. To support these tests, presence/absence for each code for each paragraph was obtained via ATLAS.ti's export feature. Both Pearson chi-squared and Spearman rank correlation tests were conducted. Anticipating insufficient " $n$ " for numerous cells in a full crosstabulation matrix, tests of association were planned for codes grouped into categories. In formulating hypotheses for how attributes and motivations might be linked, we recategorized attributes as follows: basic needs or harm, recreation, and remaining codes. Testing against the null of independence, our alternate hypothesis was that these categories would be associated 
with consumptive use, nonconsumptive use, and not use contingent motivations, respectively. The recategorization proved challenging because some attributes reasonably span multiple categories, for example mammals (MAMM) might be in the context of direct use (hunting), passive use (wildlife viewing), or nonuse (preserving for the future). However this difficulty is precisely the reason we wanted to conduct association tests. Attributes associated with consumptive and nonconsumptive use are somewhat predictable, yet attributes not associated with direct or indirect use are more difficult to hypothesize. To complete the recategorization, we took a conservative approach and only placed codes clearly related to basic needs or harm, or recreation, in those two respective categories. The third category, remaining codes, contained everything that could not be reasonably ascribed solely to a use-type motivation. All statistics were conducted with $\mathrm{R}$ software ( $\mathrm{R}$ Core Team 2014), with multivariate analyses performed using the vegan package for $\mathrm{R}$ (Oksanen et al. 2015).

\section{RESULTS}

A foundational result of the study is the codebook itself, extensively tested to reliably extract the variety of measurable attributes of rivers and streams as well as human motivations for interest in those attributes. The full codebook with coding rules is attached as Appendix 1, with code shorthands and brief descriptions shown in Table 1. For attribute codes, the original and alternative code groupings for statistical tests of association are shown in Table 2. Note that two motivation codes listed in the codebook, medicinal uses (MED) and rights of species (RIGHT) were never actually used in our sample. The total number of utilized codes is then 52 .

In all, the 76 sampled texts contained 1273 paragraphs and 2979 code occurrences (with 214 of those being NOCODE). To provide examples of how codes applied to actual text, selections for each utilized code are listed in Appendix 2. To provide further context on the codes, Appendix 2 also briefly describes subthemes arising under each code. To document the sampled texts themselves, and additional background beyond code frequencies, Appendix 3 lists a synopsis alongside each article title.

For reporting summary statistics, the NYT and WSJ are pooled because MANOVA results (described next) showed no discernible difference between these sources. Two bar charts, Figures 1 and 2, show normalized code frequencies for attributes and motivations, respectively. Box plots in Figures 3 and 4 show normalized code frequencies aggregated by category. Overall, code occurrences are split $54.4 \%$ attributes, $38.4 \%$ motivations, and $7.2 \%$ NOCODE.

Nonparametric MANOVA tests for differences in normalized code frequencies across articles are summarized in Tables 3 and 4. Article source, year, and season were tested, as well as sourceyear and source-season interactions. Initially MANOVAS were run on all the data, with separate runs for attribute and motivation code frequencies. These tests showed only source to be a significant variable ( $\mathrm{p}$-value $<0.05$ ). Thus, three follow-up pairwise tests were run to isolate which sources differed from each other. Although the blog differed from both the NYT and the WSJ, no difference was found between the latter two.
Table 1. Attribute and motivation categories, codes, and shorthands.

\begin{tabular}{|c|c|}
\hline Code Meaning and Hierarchy & $\begin{array}{l}\text { Code } \\
\text { Shorthand }\end{array}$ \\
\hline \multicolumn{2}{|l|}{ Attributes } \\
\hline \multicolumn{2}{|l|}{ Water } \\
\hline \multicolumn{2}{|l|}{ Water Quantity } \\
\hline Water supply scarcity & WSS \\
\hline Flooding damage & FD \\
\hline Flooding hazards & FHZ \\
\hline Flooding other & $\mathrm{FO}$ \\
\hline Water quantity other & QUANO \\
\hline \multicolumn{2}{|l|}{ Water Quality } \\
\hline Contact health risk & CHR \\
\hline Water supply health risk & WSHR \\
\hline Movement & MVMT \\
\hline Sound & SND \\
\hline Swimming hazards & SHZ \\
\hline Clarity & CLAR \\
\hline Odor & ODOR \\
\hline Sewage & SEW \\
\hline Water quality other-specific & QUALSP \\
\hline Water quality other & QUALO \\
\hline \multicolumn{2}{|l|}{ Fish and Wildlife and Vegetation } \\
\hline \multicolumn{2}{|l|}{ Aquatic Wildlife } \\
\hline Fish & FISH \\
\hline Other aquatic & AQO \\
\hline \multicolumn{2}{|l|}{ Land Wildlife } \\
\hline Mammals & MAMM \\
\hline Birds & BRD \\
\hline \multicolumn{2}{|l|}{ Other Wildlife } \\
\hline Other wildlife & WLO \\
\hline \multicolumn{2}{|l|}{ Vegetation } \\
\hline Trees & TR \\
\hline Other vegetation & VEGO \\
\hline \multicolumn{2}{|l|}{ Overarching Codes for Fish, Wildlife, Vegetation } \\
\hline Pristine, untouched & PRIS \\
\hline Unusual, unique & UNUS \\
\hline Endangered species & ENDG \\
\hline Sensitive species & SENS \\
\hline Native species & NSPEC \\
\hline Biodiversity & BIOD \\
\hline Nuisance & NUIS \\
\hline \multicolumn{2}{|l|}{ Channel } \\
\hline Safety of navigation & SNAV \\
\hline Rocks & ROK \\
\hline Channel or watershed statistics & LAREA \\
\hline \multicolumn{2}{|l|}{ 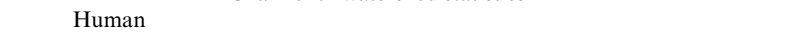 } \\
\hline Access & $\mathrm{ACC}$ \\
\hline Negative infrastructure & NEGINF \\
\hline Recreation amenities & RECAM \\
\hline Maintenance of area & CARE \\
\hline Other users & USENEG \\
\hline Motivations & \\
\hline Consumptive Use & \\
\hline Agricultural & AG \\
\hline Industrial and commercial & IND \\
\hline Residential & RES \\
\hline Tribal & TRIB \\
\hline Hunting or gathering & HUNT \\
\hline Medicinal discoveries & MED \\
\hline Nonconsumptive Use & \\
\hline Water contact recreation & CREC \\
\hline Passive outdoor recreation & PREC \\
\hline Mental or emotional health & MENTAL \\
\hline Not Use Contingent & \\
\hline Preserve for future & PRES \\
\hline Rights of species & RIGHT \\
\hline Nature's balance & NBAL \\
\hline Human greed or overuse & GREED \\
\hline Education & EDUC \\
\hline Supposed to be & SUPP \\
\hline Self-sustaining & SELFS \\
\hline Other & \\
\hline No code present in paragraph & NOCODE \\
\hline
\end{tabular}


Table 2. Original and recategorized attribute categories.

Original Hierarchy

Water

Fish and Wildlife and Vegetation Channel

Human

Alternative Hierarchy

Basic Needs or Harm

Recreation

Remaining
CHR; CLAR; FD; FHZ; FO; MVMT; ODOR; QUALO; QUALSP; QUANO; SEW; SHZ; SND;

WSHR; WSS

AQO; BIOD; BRD; ENDG; FISH; MAMM; NSPEC; NUIS; PRIS; SENS; TR; UNUS; VEGO; WLO

LAREA; ROK; SNAV

ACC; CARE; NEGINF; RECAM; USENEG

FD; FHZ; WSHR; WSS

ACC; CARE; CHR; CLAR; MVMT; NEGINF; NUIS; ODOR; RECAM; SHZ; SNAV; SND;

USENEG

AQO; BIOD; BRD; ENDG; FISH; FO; LAREA; MAMM; NSPEC; PRIS; QUALO; QUALSP; QUANO; ROK; SENS; SEW; TR; UNUS; VEGO; WLO
Fig. 1. Attribute normalized frequencies, see Appendix 1 for long form code descriptions.

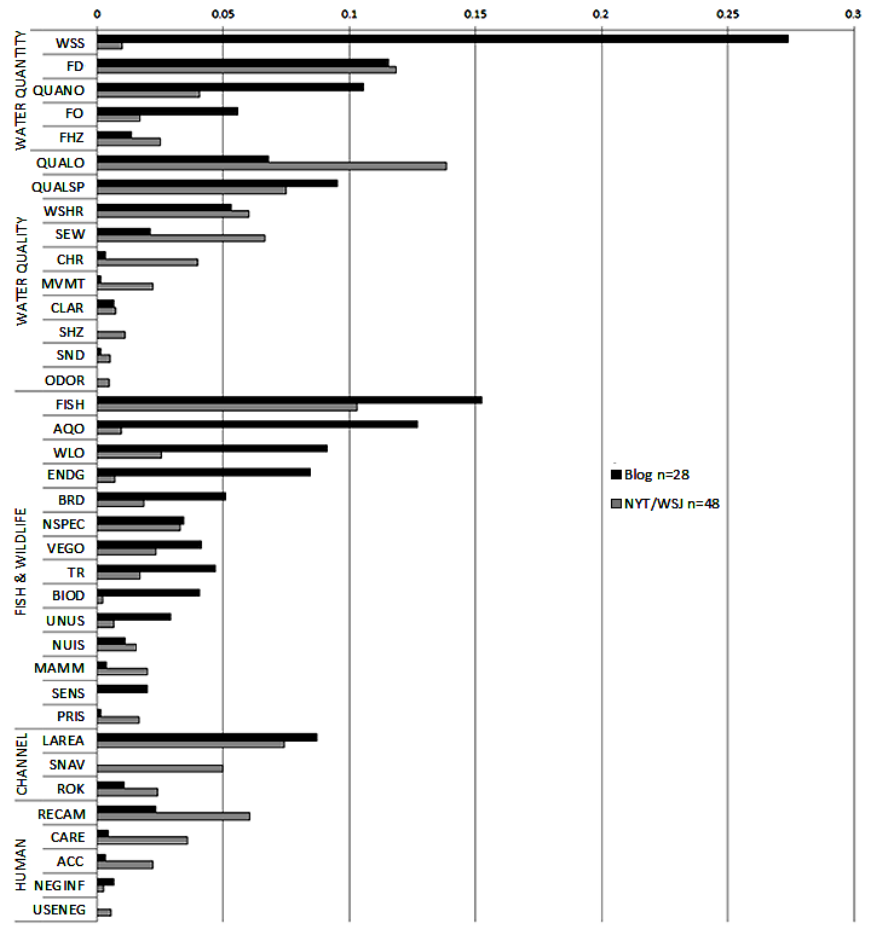

The MANOVA results indicate significant differences between the blog and the NYT/WSJ, but particular code frequencies driving the difference are not specified. The NMS plots in Figures 5 and 6 provide visualizations of complex differences between individual articles. The NMS vectors are filtered to show only combined correlations over 0.3 , to isolate codes that account for a larger degree of difference.

The outcome of chi-squared and Spearman rank correlation tests for the three hypothesized relationships are shown in Table 5. All expected associations were significant, with p-values well below 0.01 and with the correlation between remaining attributes and not use contingent motivations being the strongest of the three. Given
Fig. 2. Motivation normalized frequencies, see Appendix 1 for long form code descriptions.

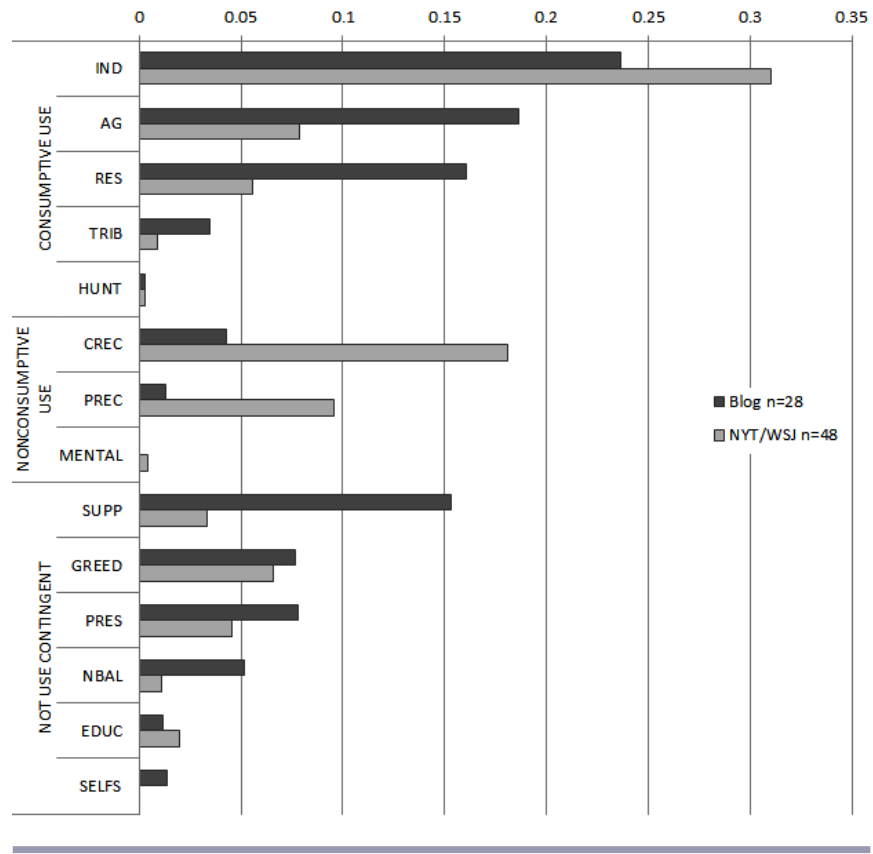

the uncertainty of particular attributes associated with nonuse motivations, a simple contingency table of co-occurring remaining attributes and not use contingent motivations was queried (table not shown). Out of 19 attributes represented in the table, just 3 accounted for more than one third of the 368 co-occurrences: fish (FISH), water quality other (QUALO), and wildlife other (WLO). Given this strong link between fish and wildlife codes and not use contingent motivations, we were then curious how the fish and wildlife and vegetation attribute category correlated with each of the three motivation categories. Correlations were rather low for consumptive use and nonconsumptive use at 0.05 and 0.02 , respectively, whereas the correlation with not use contingent was 0.45 . 
Fig. 3. Attribute category box plots, see Figure 1 for codes contained within each category.

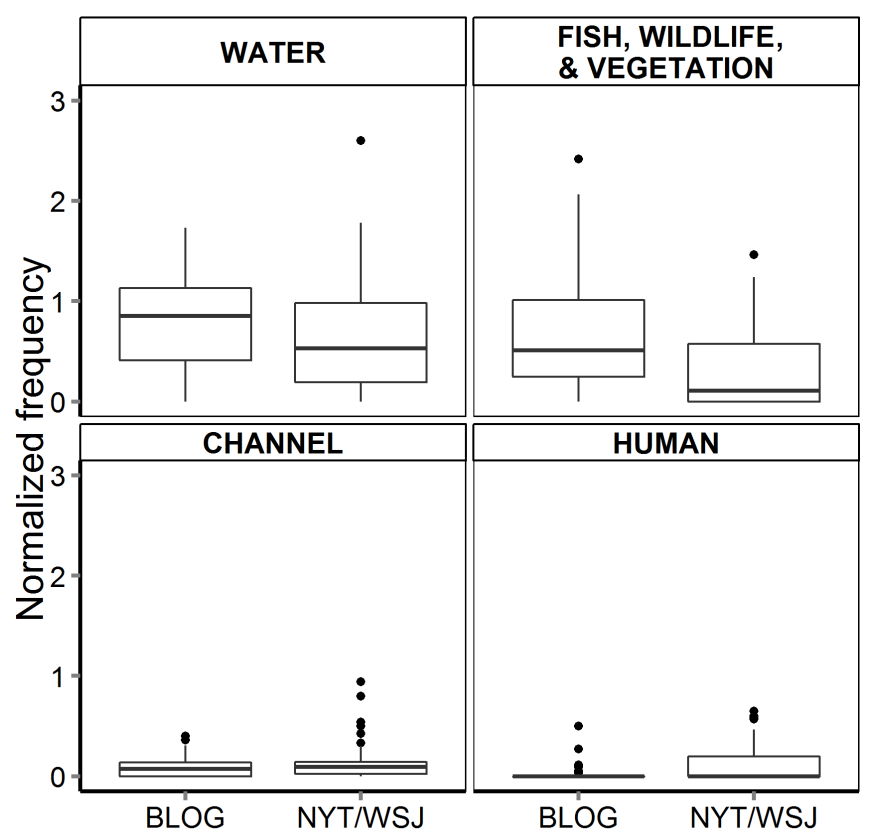

Fig. 4. Motivation category box plots, see Figure 2 for codes contained within each category.

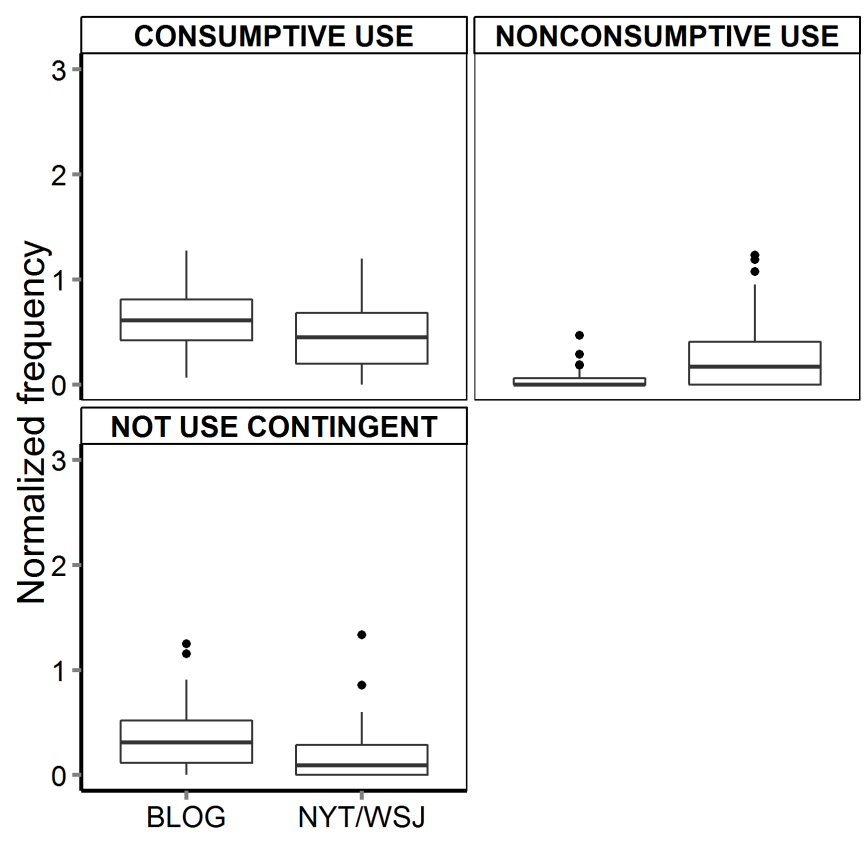

Table 3. Sequence of multivariate analysis of variance results for attributes.

\begin{tabular}{|c|c|c|c|}
\hline Attributes & $\mathrm{df}$ & F Statistic & $\mathrm{p}$-value \\
\hline \multicolumn{4}{|l|}{ All Sources } \\
\hline Source & 2 & 3.11625 & $0.001 * * *$ \\
\hline Year & 1 & 1.01038 & 0.398 \\
\hline Season & 3 & 1.16435 & 0.230 \\
\hline Source X Year & 2 & 0.64498 & 0.912 \\
\hline Source X Season & 5 & 1.00180 & 0.438 \\
\hline Residuals & 62 & & \\
\hline Total & 75 & & \\
\hline \multicolumn{4}{|l|}{ Blog vs. NYT } \\
\hline Source & 1 & 4.7235 & $0.001 * * *$ \\
\hline Residuals & 66 & & \\
\hline Total & 67 & & \\
\hline \multicolumn{4}{|l|}{ Blog vs. WSJ } \\
\hline Source & 1 & 2.4185 & $0.013 *$ \\
\hline Residuals & 34 & & \\
\hline Total & 35 & & \\
\hline \multicolumn{4}{|l|}{ NYT vs. WSJ } \\
\hline Source & 1 & 1.1382 & 0.279 \\
\hline Residuals & 46 & & \\
\hline Total & 47 & & \\
\hline
\end{tabular}

Table 4. Sequence of multivariate analysis of variance results for motivations.

\begin{tabular}{|c|c|c|c|}
\hline Motivations & df & F Statistic & p-value \\
\hline \multicolumn{4}{|l|}{ All Sources } \\
\hline Source & 2 & 2.74113 & $0.005 * *$ \\
\hline Year & 1 & 0.76557 & 0.612 \\
\hline Season & 3 & 0.68092 & 0.839 \\
\hline Source X Year & 2 & 0.70970 & 0.756 \\
\hline Source X Season & 5 & 1.55297 & 0.058 \\
\hline Residuals & 62 & & \\
\hline Total & 75 & & \\
\hline \multicolumn{4}{|l|}{ Blog vs. NYT } \\
\hline Source & 1 & 4.7235 & $0.001 * * *$ \\
\hline Residuals & 66 & & \\
\hline Total & 67 & & \\
\hline \multicolumn{4}{|l|}{ Blog vs. WSJ } \\
\hline Source & 1 & 2.4185 & $0.017 *$ \\
\hline Residuals & 34 & & \\
\hline Total & 35 & & \\
\hline \multicolumn{4}{|l|}{ NYT vs. WSJ } \\
\hline Source & 1 & 1.1382 & 0.303 \\
\hline Residuals & 46 & & \\
\hline Total & 47 & & \\
\hline \multicolumn{4}{|c|}{$\begin{array}{l}*=\text { significant at the } 5 \% \text { level } \\
* *=\text { significant at the } 1 \% \text { level } \\
* * *=\text { significant at the } 0.1 \% \text { level }\end{array}$} \\
\hline
\end{tabular}


Table 5. Summary of chi-squared and Spearman rank correlation tests for code aggregations.

\begin{tabular}{llcc}
\hline \hline Attribute Code Category & Motivation Code Category & Chi-Squared Statistic (p-value) & $\begin{array}{c}\text { Spearman Rank Correlation (p- } \\
\text { value) }\end{array}$ \\
\hline Basic Needs or Harm & Consumptive Use & $30.21(<0.0001)$ & $0.30(0.009)$ \\
Recreation & Nonconsumptive Use & $172.02(<0.0001)$ & $0.54(<0.0001)$ \\
Remaining & Not Use Contingent & $39.32(<0.0001)$ & $0.56(<0.0001)$ \\
\hline
\end{tabular}

Fig. 5. Nonmetric Multidimensional Scaling plot for Attributes, see Appendix 1 for long form code descriptions.

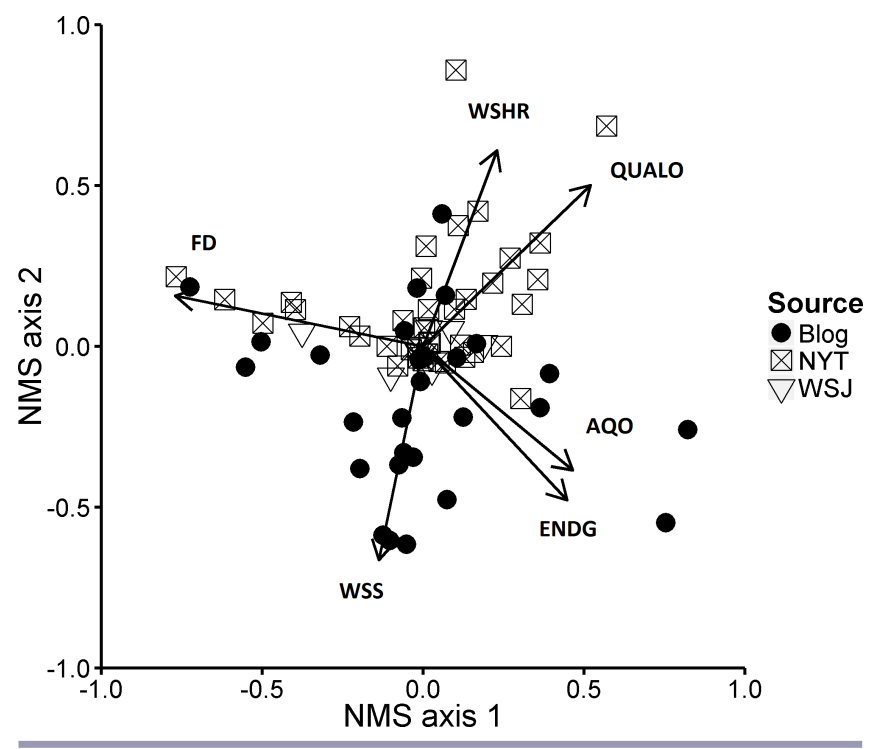

Fig. 6. Nonmetric multidimensional scaling plot for motivations, see Appendix 1 for long form code descriptions.

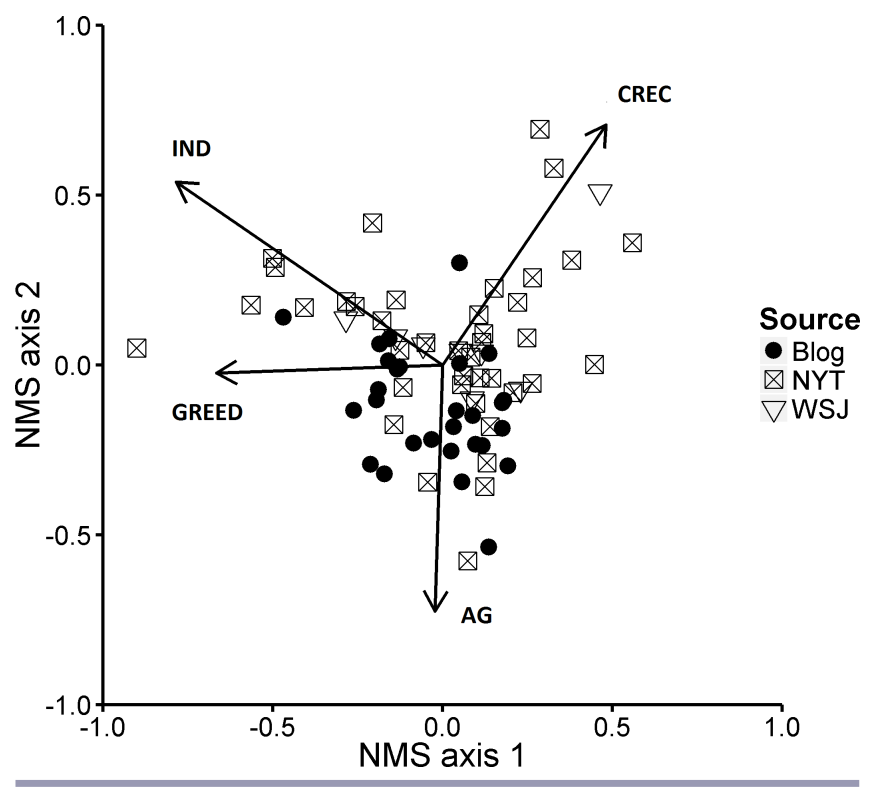

\section{DISCUSSION}

Simple bar charts and box plots provided in Figures 1 through 4 tell much of the story regarding relative frequency of different codes and code categories, as well as comparisons across article sources. Within attributes, water codes are most common, with fish, wildlife, and vegetation codes being a close second. Within motivations, consumptive use codes are the most frequent. The box plots show the blog and NYT/WSJ having similar rankings at the highest code category level, however, contrasts are seen when inspecting the finer resolution available on the bar charts. The blog is enriched in water quantity attributes, fish and wildlife and vegetation attributes, and not use contingent motivations. The NYT/WSJ has more water quality attributes, human attributes, and nonconsumptive use motivations. There are also notable differences at the code level. For example, viewing Figure 1 , the blog focuses on water supply scarcity (WSS), whereas the NYT/WSJ barely mentions it.

The NMS plots are useful for summarizing results at the article level. Figure 5, dedicated to attributes, indicates some clustering of blog articles toward the lower half of axis 2, which is associated with water supply scarcity (WSS). The NYT articles tended toward the opposite direction, more closely associated with water supply health risk (WSHR) and water quality other (QUALO: general reference to water quality). Furthermore, there are a few blog articles, in the lower right quadrant, associated with aquatic life other (AQO: nonfish aquatic animals) and endangered species (ENDG). Property damage from flooding (FD) is an arm of the data shared by all sources. The Figure 1 bar chart substantiates source differences for WSS, QUALO, AQO, and ENDG; however average WSHR code frequencies are similar. It appears that just one or two NYT articles with especially high code frequencies are driving the WSHR vector to appear as a factor describing differences between articles.

Turning to motivations, Figure 6 indicates that blog and NYT articles share interest in agriculture (AG), with a particularly strong signature in the blog. The NYT/WSJ shows clustering in the directions of industry (IND) and contact recreation (CREC). Overuse (GREED) also appears as an important vector, but with few articles plotted nearby. Cross-checking Figure 6 with Figure 2, differences between sources for AG and CREC are corroborated, with some difference in IND, although IND remains the most prevalent motivation for both sources. Average code frequencies for GREED are similar, indicating this to be a factor more for describing differences between articles than for between sources.

The above discussion draws on data to visualizations to highlight overall results and other easily visible insights. However, our analysis also benefits from a foundation of careful sampling, allowing statistical testing. The MANOVA tests find significant 
differences between the blog and combined NYT/WSJ sources. Tests of association also yielded statistically significant results in a manner that would be impossible through visual inspection. Quantitative analysis was successful in documenting consistent patterns in the data, regarding influence of text source, and even predictable correlations between codes at the paragraph level across sources. Quantitative evidence of these patterns is especially compelling given that article topics varied widely, i.e., everything from flooding on the Mississippi, to a controversial art project that would drape shade over a river in Colorado.

Our findings mark a new threshold in final ecosystem services identification. Preceding work has refocused ecosystem services concepts in the direction of measurable specifics, along with a call for more research on identifying those final services (or other similarly named term) at the interface between biophysical science and social systems (Boyd and Banzhaf 2007, Fisher et al. 2009, Johnston and Russell 2013). Some investigators have continued to concentrate on theoretic issues or other top-down structures, such as Boyd and Krupnick (2013), Landers and Nahlik (2013), and Boyd et al. (2016). Others have directed efforts toward bottom-up data collections using social science methods to document valued attributes in a reproducible manner. Furthermore, other empirical efforts have been ongoing for decades to isolate and then value specific environmental resources in case study work (Mitchell and Carson 1989, Arrow et al. 1993, Bateman et al. 2003, Weber et al. 2016).

A complete joining of top-down and bottom-up insights relevant for final ecosystem services is beyond our scope and would constitute an enormous effort indeed. However, we attempted a limited summary of how our research compares and connects with other studies attempting to identify the breadth of river final services. In that vein of research, Ringold et al. (2009) established a pattern by outlining a matrix of beneficiaries on one axis and categories of measurable river quantities on the other. The matrix was derived via an expert workshop of diverse attendees and served to broaden ideas of river monitoring beyond traditional indices. There is much overlap in their expert assessment and our content analysis results, however, there are also many differences. Most meaningfully, there was no attempt to assign relative importance to different river attributes, and workshop results were stated to be a hypothesis requiring follow-up study. Further development of attribute-by-beneficiary matrices continued with Ringold et al. (2013) and most ambitiously with Landers and Nahlik (2013). However, these continued to be limited to expert judgments regarding what attributes different groups of people valued.

Schiller et al. (2001) and later Weber and Ringold (2014, 2015) executed qualitative data collections to isolate river attributes as evident in focus group and semistructured interview transcripts. The latter 2 efforts involved more than 200 human subjects in 2 separate U.S. geographies, with code frequencies reported in results, allowing a measure of relative priority. Taken together, the studies provided the initial working codebook for our work (as noted in the introduction), and thus cannot be considered truly independent. That said, there is an important contrast in methods. Our study relied on secondary data, which despite many advantages, did not allow the ability to follow up for clarification as during a live meeting. Thus, our study is more susceptible to coding intermediate ecosystem services, i.e., measurable attributes not important in and of themselves, but instead indicators of other, more relevant attributes. For example, one of our codes was sewage (SEW). Although people are certainly likely to have an immediate distaste for sewage in waterways, there are a host of potentially related concerns that may or may not have been actually written out, such as safety of water contact, safety of water supplies, and health of aquatic life.

Despite differences in data sources and methods, code rankings are similar across our study and Weber and Ringold (2014, 2015). There tends to be a focus on charismatic flora and fauna, and attributes that could cause direct harm to humans, such as poor drinking water quality, or flooding risk. However, there is also consistent concern for topics such as native species, evidencing widespread environmentalist perspectives to some degree. All three studies were designed to identify river attributes important to so-called nonusers, a classic category in resource economics (Krutilla 1976) and ecosystem services (Chan et al. 2012). Weber and Ringold (2014, 2015) specifically screened for diverse participants, including those with minimal recreational contact with rivers. Their results show consolidation of interest around a limited number of final services across socio-demographics, with just a few notable differences (e.g., between urban vs. rural participants). Their results do not show evidence of particularities for nonuser participants, e.g., codes only relevant to nonusers, or nonuser lack of interest in codes other groups were interested in. We isolated a nonconsumptive use motivation code category and statistically tested correlation with a remaining attributes code category. As noted in the results, fish (FISH) and wildlife other (WLO) were prevalent in that association, leading to the subsequent discovery that fish and wildlife and vegetation attributes were most closely correlated with not use contingent motivations. This provides evidence that fish and wildlife are not solely associated with extractive or recreational motivations. Our findings challenge the common supposition that people value fish, wildlife, and vegetation primarily for direct or indirect uses. Instead, sampled texts more commonly associate not use contingent motivations with these attributes.

\section{SPECULATION}

There is an important question regarding how well the particular texts we sampled represent public opinion or even their readership. Significant editorial bias from publishing entities is possible and some criticize news sources as being sensationalistic in general. A counterargument is that news media is an integrated component of popular culture (Altheide and Schneider 2013). Furthermore, periodicals may themselves influence public perceptions of environmental issues or management (Siemer et al. 2007, Muter et al. 2009, Lopera and Moreno 2014). Although we are only able to analyze a relatively small number of texts, we have endeavored to include archetypal representations of different points of view. Texts from additional perspectives would be interesting to examine, such as agricultural, industrial, or tribal sources. Monograph texts, such as books on rivers and streams by high-profile authors are another possibility. With regard to closer qualitative analysis of data already in hand, more of the complex context surrounding how different codes were presented could be drawn out. For example, FD has a similar frequency for the two sources, but the blog emphasized the idea of using wetlands and similar strategies to prevent FD, whereas the NYT/ 
WSJ focused more on occurrences of FD. As noted earlier, Appendix 3 briefly notes such subthemes.

A related question is how well our results would continue to represent popular interests in the future, or even the present day, given that the articles analyzed are several years old. Undoubtedly public perceptions and interests evolve over time, and we must leave the question unanswered as to how different results would be if a similar content analysis were performed in 5, 10, or 50 years. However, we suspect that although specific newsworthy details vary, such as the specific threat to clean drinking water, the location of flooding, or the particular invasive species, most of the same final ecosystem services will continue to be discussed. We did take pains to investigate this question statistically, specifically testing for influence of year and season. We found no effect with either, but the test was limited by the data only spanning two years.

\section{CONCLUSIONS}

To shed light on attributes of waterways people care about and the motivations for their interest, we conducted a content analysis of both environmentalist and mainstream texts. Our codebook was rigorously tested via a pilot phase and is itself an outcome of the study that may be useful as a basis for future empirical studies of final ecosystem services. For attributes, the most common codes were regarding water quantity and quality, fish, wildlife, and vegetation. The most common motivation codes were about consumptive use. Somewhat surprisingly, these high-level results were similar across sources, although statistical testing indicated that text source significantly influenced code frequencies overall. Closer inspection of the data via both code-level bar charts and article-level nonmetric multidimensional scaling plots showed that the selected environmentalist source more strongly emphasized water supply scarcity, aquatic life besides fish, endangered species, and motivations not contingent on use. The two mainstream news sources more frequently discussed water quality generally and recreational motivations. Influence of publication date on code frequencies was also tested, but was found insignificant. At a paragraph level, expected co-occurrences between categories of attribute and motivation codes were strong. Some attribute codes were more associated with motivations not contingent on use, rather than direct use or recreational enjoyment. One notable example of this was fish, the most common wildlife code for both sources. These results lend support to the importance of nonuse oriented ecological values in both environmentalist and mainstream news sources. Despite differences between sources, overall most of the interest in rivers consolidates around relatively few codes, a finding that triangulates with previous focus group and semistructured interview research.

We believe our methodology would serve for other kinds of socialecological systems research, and indeed, the main appeal of our paper to other researchers may lie in the methods rather than the results. In the spectrum between qualitative and quantitative approaches, we found ourselves in the middle, due to the detail we wished to glean from texts, and our goal of statistical testing. We found few examples of content analysis matching our level of detail, and by necessity forged our own way forward. We ultimately succeeded in drawing on the advantages of both qualitative and quantitative traditions, thanks to an interdisciplinary team, with much effort toward careful sample design, manual coding, and the benefit of specialized visualization and statistical methods. Even so, our codebook detail pushes the limit of manual content analysis, and we recommend fewer codes for future work if possible. Vast research possibilities exist with online data, and we hope our method opens doors for quantitative analysis of qualitative data, for investigators having the necessary human resources but limited research dollars.

Responses to this article can be read online at: http://www.ecologyandsociety.org/issues/responses. $\mathrm{php/9496}$

\section{Acknowledgments:}

The authors are grateful to Claire Cvitanovich and Brian Wilson for their careful coding and to Susan Yee for helpful comments on an earlier draft of this paper. This manuscript has been subjected to the U.S. Environmental Protection Agency review and has been approved for publication. The views expressed in this paper are those of the authors and do not necessarily reflect the views or policies of the U.S. Environmental Protection Agency. Mention of trade names or commercial products does not constitute endorsement or recommendation for use.

\section{LITERATURE CITED}

Alessi, M. G., C. A. Miller, and E. E. Harper. 2013. Content analysis of three waterfowl hunting DVDs. Human Dimensions of Wildlife 18.2:152-158. http://dx.doi.org/10.1080/10871209.2013.745103

Alexander, S. M., and M. S. Quinn. 2011. Coyote (Canis latrans) interactions with humans and pets reported in the Canadian print media (1995-2010). Human Dimensions of Wildlife 16.5:345-359.

Altheide, D. L., and C. J. Schneider. 2013. Field notes and other data: accounting for ourselves. Pages 125-132 in D. L. Altheide and C. J. Schneider, editors. Qualitative media analysis. Sage, Thousand Oaks California, USA.

Anderson, Marti J. 2001. A new method for non-parametric multivariate analysis of variance. Austral Ecology 26(1):32-46.

Andsager, J. L., and A. Powers. 1999. Social or economic concerns: how news and women's magazines framed breast cancer in the 1990s. Journalism and Mass Communication Quarterly 76 (3):531-550. http://dx.doi.org/10.1177/107769909907600309

Arrow, K., R. Solow, P. R. Portney, E. E. Leamer, R. Radner, and H. Schuman. 1993. Report of the NOAA panel on contingent valuation. Federal Register 58(10):4601-4614.

Bateman, I. J., R. T. Carson, B. Day, W. M. Hanemann, N. Hanley, T. Hett, M. Jones-Lee, G. Loomes, S. Mourato, E. Özdemiroglu, D. W. Pierce, R. Sugden, and J. Swanson. 2002. Economic valuation with stated preference surveys: a manual. Edward Elgar, Northampton, Massachusetts, USA.

Bengston, D. N., T. J. Webb, and D. P. Fan. 2004. Shifting forest value orientations in the United States, 1980-2001: a computer content analysis. Environmental Values 13:373-392. http://dx.doi. org/10.3197/096327104323312734 
Bernard, H. R. 2011. Research methods in anthropology. AltaMira, Lanham, Maryland, USA.

Böck, K., S. Muhar, A. Muhar, and R. Polt. 2015. The ecosystem services concept: gaps between science and practice in river landscape management. GAIA 24(1):32-40. http://dx.doi. org/10.14512/gaia.24.1.8

Boyd J. W., and S. Banzhaf. 2007. What are ecosystem services? The need for standardized environmental accounting units. Ecological Economics 63:616-626. http://dx.doi.org/10.1016/j. ecolecon.2007.01.002

Boyd, J., and A. Krupnick. 2013. Using ecological production theory to define and select environmental commodities for nonmarket valuation. Agricultural and Resource Economics Review 42(1):1-32. http://dx.doi.org/10.1017/S1068280500007590

Boyd, J., P. Ringold, A. Krupnick, R. Johnston, M. Weber, and K. Hall. 2016. Ecosystem services indicators: improving the linkage between biophysical and economic analyses. International Review of Environmental and Resource Economics 8(3-4).

Braden, J. B., D. G. Brown, D. R. Maidment, and S. T. MarquartPyatt. 2015. Populating the water world: exploring data aspirations of water experts. Society and Natural Resources 28:439-451. http://dx.doi.org/10.1080/08941920.2014.945060

Brossard, D., J. Shanahan, and K. McComas. 2004. Are issuecycles culturally constructed? A comparison of French and American coverage of global climate change. Mass Communication and Society 7(3):359-377. http://dx.doi. org/10.1207/s15327825mcs0703_6

Chan, K. M. A, T. Satterfield, and J. Goldstein. 2012. Rethinking ecosystem services to better address and navigate cultural values. Ecological Economics 74:8-18. http://dx.doi.org/10.1016/j. ecolecon.2011.11.011

Clarke, K. R. 1993. Non-parametric multivariate analyses of changes in community structure. Australian Journal of Ecology 18:117-143. http://dx.doi.org/10.1111/j.1442-9993.1993.tb00438. $\underline{\mathrm{X}}$

Creswell, J. W. 2014. Research design: qualitative, quantitative, and mixed methods approaches. Sage, Thousand Oaks, California, USA.

Daily, G. C. 1997. Nature's services: societal dependence on natural ecosystems. Island, Washington, D.C., USA.

Fisher, B., R. K. Turner, and P. Morling. 2009. Defining and classifying ecosystem services for decision making. Ecological Economics 68(3):643-653. http://dx.doi.org/10.1016/j. ecolecon.2008.09.014

Fleiss, J. L. 1971. Measuring nominal scale agreement among many raters. Psychological Bulletin 76:378-382. http://dx.doi. org/10.1037/h0031619

Freeman, III, A. M. 2003. The measurement of environmental and resource values. Resources for the Future, Washington, D.C., USA.

Gerbert, B., N. Caspers, A. Bronstone, J. Moe, and P. Abercrombie. 1999. A qualitative analysis of how physicians with expertise in domestic violence approach the identification of victims. Annals of Internal Medicine 131(8):578-584. http://dx. doi.org/10.7326/0003-4819-131-8-199910190-00005

Gunter, V. J., and C. K. Harris. 1998. Noisy winter: the DDT controversy in the years before Silent Spring. Rural Sociology 63 (2):179-198. http://dx.doi.org/10.1111/j.1549-0831.1998.tb00670. $\underline{\mathrm{x}}$

Gunter, V. J. 2005. News media and technological risks: the case of pesticides after Silent Spring. Sociological Quarterly 46 (4):671-698. http://dx.doi.org/10.1111/j.1533-8525.2005.00031.x

Haines-Young, R., and M. Potschin. 2010. The links between biodiversity, ecosystem services and human well-being. Pages 110-139 in D. G. Raffaelli and C. L. J. Frid, editors. Ecosystem ecology: anew synthesis. Cambridge University Press, Cambridge, UK. [online] URL: https://www.nottingham.ac.uk/cem/pdf/ Haines-Young\&Potschin 2010.pdf

Houston, M. J., J. T. Bruskotter, and D. Fan. 2010. Attitudes toward wolves in the United States and Canada: a content analysis of the print news media, 1999-2008. Human Dimensions of Wildlife 15(5):389-403. http://dx.doi.org/10.1080/10871209.2010.507563

Janis, I. L. 1972. Victims of groupthink: a psychological study of foreign-policy decisions and fiascoes. Houghton Mifflin, Boston, Massachusetts, USA.

Johnston, R. J., E. Y. Besedin, and R. F. Wardwell. 2003. Modeling relationships between use and nonuse values for surface water quality: a meta-analysis. Water Resources Research 39(12). http:// dx.doi.org/10.1029/2003WR002649

Johnston, R. J., and M. Russell. 2011. An operational structure for clarity in ecosystem service values. Ecological Economics 70 (12):2243-2249. http://dx.doi.org/10.1016/j.ecolecon.2011.07.003

Keeler, B. L., S. Polasky, K. A. Brauman, K. A. Johnson, J. C. Finlay, A. O’Neill, K. Kovacs, and B. Dalzel. 2012. Linking water quality and well-being for improved assessment and valuation of ecosystem services. Proceedings of the National Academy of Sciences 109(45):18619-18624. http://dx.doi.org/10.1073/pnas.1215991109

Krippendorff, K. 2013. Content analysis: an introduction to its methodology. Third Edition. Sage, Thousand Oaks, California.

Krutilla, J. V. 1967. Conservation reconsidered. American Economic Review 57:777-786. [online] URL: http://www.rff.org/ files/sharepoint/News/Features/Documents/071003\%20KrutillaConservationReconsidered.pdf

Landers, D. H., and A. M. Nahlik. 2013. Final ecosystem goods and services classification system (FEGS-CS). United States Environmental Protection Agency, Washington, D.C., USA. [online] URL: https://cfpub.epa.gov/si/si public record report. cfm?dirEntryId $=257922$

Lopera, E., and C. Moreno. 2014. The uncertainties of climate change in Spanish daily newspapers: content analysis of press coverage from 2000 to 2010. Journal of Science Communication $1: 1-18$.

Mackey, R.A., M. A. Diemer, and B. A. O'Brien. 2004. Relational factors in understanding satisfaction in the lasting relationships of same-sex and heterosexual couples. Journal of Homosexuality 47(1):111-136. http://dx.doi.org/10.1300/J082v47n01 07 
McCune, B., and J. B. Grace. 2002. Analysis of ecological communities. MjM Software Design, Gleneden Beach, Oregon, USA.

Millennium Ecosystem Assessment. 2005. Ecosystems and human well-being: synthesis. Island, Washington, D.C., USA. [online] URL: http://millenniumassessment.org/documents/document.356. aspx.pdf

Mitchell, R. C., and R. T. Carson. 1989. Using surveys to value public goods: the contingent valuation method. Resources for the Future, Washington, D.C., USA.

Muter, B. A., M. L. Gore, and S. J. Riley. 2009. From victim to perpetrator: evolution of risk frames related to human-cormorant conflict in the Great Lakes. Human Dimensions of Wildlife 14 (5):366-379. http://dx.doi.org/10.1080/10871200903045210

National Research Council. 2004. Valuing ecosystem services: toward better environmental decision-making. National Academies Press, Washington, D.C., USA. http://dx.doi.org/10.17226/11139

Nature Conservancy. 2010. Communicating ecosystem services. Nature Conservancy, Arlington, Virginia, USA. [online] URL: https://www.conservationgateway.org/ConservationPractices/ EcosystemServices/CommunicatingEcosystemServices/Pages/ communicating-ecosystem-s.aspx

Nelson, P., N. Krogman, L. Johnston, and C. C. St. Clair. 2014. Dead ducks and dirty oil: media representations and environmental solutions. Society and Natural Resources 28:345-359. http://dx.doi.org/10.1080/08941920.2014.948241

Neuendorf, K. A. 2002. The content analysis guidebook. Sage, Thousand Oaks, California, USA.

Norton, R. K. 2008. Using content analysis to evaluate local master plans and zoning codes. Land Use Policy 25(3):432-454. http://dx.doi.org/10.1016/j.landusepol.2007.10.006

Oksanen, J., F. G. Blanchet, R. Kindt, P. Legendre, P. R. Minchin, R. B. O'Hara, G. L. Simpson, P. Solymos, M. H. H. Stevens, and H. Wagner. 2015. Vegan: community ecology package. R package version 2.2-1. R Foundation for Statistical Computing, Vienna, Austria. [online] URL: http://CRAN.R-project.org/package= vegan

Proctor, J. D. 1998. Environmental values and popular conflict over environmental management: a comparative analysis of public comments on the Clinton Forest Plan. Environmental Management 22(3):347-358. http://dx.doi.org/10.1007/s002679900110

ProQuest. 2017. U.S. major dailies. ProQuest, Ann Arbor, Michigan, USA. [online] URL: http://www.proquest.com/ products-services/US-Major-Dailies.html

R Core Team. 2014. R: A language and environment for statistical computing. R Foundation for Statistical Computing, Vienna, Austria. [online] URL: http://www.R-project.org/

Riffe, D., S. Lacy, and F. G. Fico. Analyzing media messages: using quantitative content analysis in research. Routledge, Abingdon, UK.

Ringold P. L., J. W. Boyd, D. Landers, and M. A. Weber. 2009. Report from the workshop on indicators of final ecosystem services for streams. EPA/600/R-09/137. U.S. Environmental Protection Agency, Washington, D.C., USA.

Ringold P. L, J. W. Boyd, D. H. Landers, and M. A. Weber. 2013. What data should we collect? A framework for identifying indicators of ecosystem contributions to human well-being. Frontiers in Ecology and the Environment 11(2):98-105. http://dx. doi.org/10.1890/110156

Schiller, A., C. T. Hunsaker, M. A. Kane, A. K. Wolfe, V. H. Dale, G. W. Suter, C. S. Russell, G. Pion, N. H. Jensen, and V. C. Konar. 2001. Communicating ecological indicators to decision makers and the public. Conservation Ecology 5(1):19. http://dx.doi. org/10.5751/ES-00247-050119

Scientific Software Development. 2015. ATLAS.ti. Version 7.5.6. Scientific Software Development, Berlin, Germany.

Shulman, S. W. 2017. Coding analysis toolkit. Texifter. [online] URL: http://cat.texifter.com/

Siemer, W. F., D. J. Decker, and J. Shanahan. 2007. Media frames for black bear management stories during issue emergence in New York. Human Dimensions of Wildlife 12(2):89-100. http://dx.doi. org/10.1080/10871200701195415

Tilt, B., and Q. Xiao. 2010. Media coverage of environmental pollution in the People's Republic of China: responsibility, coverup and state control. Media, Culture and Society 32(2):225-245. http://dx.doi.org/10.1177/0163443709355608

Wainger, L., and M. Mazzotta. 2011. Realizing the potential of ecosystem services: a framework for relating ecological changes to economic benefits. Environmental Management 48(4):710-733. http://dx.doi.org/10.1007/s00267-011-9726-0

Weber, M. A., T. Meixner, and J. C. Stromberg. 2016. Valuing instream-related services of wastewater. Ecosystem Services 21:59-71. http://dx.doi.org/10.1016/j.ecoser.2016.07.016

Weber, M. A., and P. L. Ringold. 2015. Priority river metrics for residents of an urbanized arid watershed. Landscape and Urban Planning 133:37-52. http://dx.doi.org/10.1016/j.landurbplan.2014.09.006 
Appendix 1: Codebook hierarchy, code shorthand, and coding rules.

Code Family: Attributes

\begin{tabular}{|c|c|c|}
\hline $\begin{array}{l}\text { Code Meaning \& } \\
\text { Hierarchy }\end{array}$ & Code & Rule for Coding \\
\hline \multicolumn{3}{|l|}{ Water } \\
\hline \multicolumn{3}{|l|}{ Water Quantity } \\
\hline $\begin{array}{l}\text { Water } \\
\text { Supply } \\
\text { Scarcity }\end{array}$ & WSS & $\begin{array}{l}\text { - Reference to possibility or actuality of not having enough water. } \\
\text { - Includes aquifer shortages, snowpack shortages, or rainfall shortages } \\
\text { since these are related to rivers and streams through the water cycle. } \\
\text { - Could be either a stated concern about the present or for the future, } \\
\text { i.e. "there's not currently enough water for any additional growth". } \\
\text { - Includes scarcity for environmental purposes. [Note: This usage of } \\
\text { WSS was far less common in the data.] } \\
\text { - Includes discussion of water conservation, water footprint, etc. } \\
\text { (implied scarcity). }\end{array}$ \\
\hline $\begin{array}{l}\text { Flooding } \\
\text { Damage }\end{array}$ & FD & $\begin{array}{l}\text { - Reference to damage to infrastructure or land damage from flooding. } \\
\text { - Includes flooding damage to farms. }\end{array}$ \\
\hline $\begin{array}{l}\text { Flooding } \\
\text { Hazards }\end{array}$ & FHZ & $\begin{array}{l}\text { - Flooding-related hazards to humans or domestic animals, reduced } \\
\text { access to clean water, increased disease vectors from standing water, } \\
\text { physically being carried off by flood, or stranded. }\end{array}$ \\
\hline $\begin{array}{l}\text { Flooding } \\
\text { Other }\end{array}$ & FO & $\begin{array}{l}\text { - Any other mention of flooding not associated with Damages (FD) or } \\
\text { Hazards (FHZ). } \\
\text { - Includes when flooding is referenced as positive in some way. } \\
\text { - Includes references to floodplains. }\end{array}$ \\
\hline $\begin{array}{l}\text { Water } \\
\text { Quantity } \\
\text { Other }\end{array}$ & QUANO & $\begin{array}{l}\text { - Any water quantity reference that doesn't fit with Scarcity or } \\
\text { Flooding. } \\
\text { - Includes any general reference to “water quantity". } \\
\text { - Specific flow or volume measurements go here, e.g. acre-feet, cfs. } \\
\text { - Includes interest in high flow or low flow or flow timing. But if } \\
\text { absence of flow is described as a scarcity issue, use the WSS code. If } \\
\text { high flow is described as a flood, use a flooding code. }\end{array}$ \\
\hline \multicolumn{3}{|l|}{ Water Quality } \\
\hline $\begin{array}{l}\text { Contact } \\
\text { Health Risk }\end{array}$ & CHR & $\begin{array}{l}\text { - Reference to safety of water contact for human or domestic animals } \\
\text { (does not include drinking). }\end{array}$ \\
\hline $\begin{array}{l}\text { Water } \\
\text { Supply } \\
\text { Health } \\
\text { Risk }\end{array}$ & WSHR & $\begin{array}{l}\text { - Reference to safety of water for drinking purposes for human or } \\
\text { domestic animals. } \\
\text { - Could be from drinking directly from river, or safety of tap water } \\
\text { linked to rivers, or safety of eating crops or eating livestock watered } \\
\text { with river water. } \\
\text { - Includes comments on either water supply safety or lack thereof. }\end{array}$ \\
\hline Movement & MVMT & $\begin{array}{l}\text { - This is meant to capture esthetics of movement or lack of movement. } \\
\text { - Appreciative reference to moving water, including calm shimmering } \\
\text { surface as well as remarking on spectacles such as waterfalls. }\end{array}$ \\
\hline
\end{tabular}




\begin{tabular}{|c|c|c|}
\hline & & $\begin{array}{l}\text { - Includes any positive or negative references to still water, or stagnant } \\
\text { water. }\end{array}$ \\
\hline Sound & SND & - Reference to sound of flowing water. \\
\hline $\begin{array}{l}\text { Swimming } \\
\text { Hazards }\end{array}$ & SHZ & $\begin{array}{l}\text { - Reference to swimming hazards or lack of swimming hazards, such as } \\
\text { currents, cold temperature, or hazards in the river. } \\
\text { - If downed trees are mentioned as hazardous to boaters code this as } \\
\text { SHZ and TR and NUIS (see later codes). } \\
\text { - Can include hazards associated with wading (e.g. fly fishing). }\end{array}$ \\
\hline Clarity & CLAR & $\begin{array}{l}\text { - Any reference to clarity or to non-clarity (murky). } \\
\text { - If passage says murkiness is being caused by algae, code VEGO and } \\
\text { NUIS as well. }\end{array}$ \\
\hline Odor & ODOR & - Reference to odor or lack of odor. \\
\hline Sewage & SEW & $\begin{array}{l}\text { - Reference to sewage or wastewater when it could have a residential } \\
\text { component. } \\
\text { - Includes references that can be defensibly linked to } \\
\text { sewage/wastewater (e.g. pharmaceuticals flushed down toilets). Do } \\
\text { not double-code with RES (unless another part of the quotation } \\
\text { triggers RES). Do code IND or AG if there is explicit reference to } \\
\text { IND or AG impact on sewage. }\end{array}$ \\
\hline $\begin{array}{l}\text { Water } \\
\text { Quality } \\
\text { Other- } \\
\text { Specific }\end{array}$ & QUALSP & $\begin{array}{l}\text { - A reference to a specific measureable water quality characteristic } \\
\text { besides those listed above, such as "dissolved oxygen" or "nutrients" } \\
\text { or "eutrophication". Restricted to inorganic attributes or non- } \\
\text { plant/algae/animal attributes. }\end{array}$ \\
\hline $\begin{array}{l}\text { Water } \\
\text { Quality } \\
\text { Other }\end{array}$ & QUALO & $\begin{array}{l}\text { - Any general reference to "water quality" when no other code above is } \\
\text { used. }\end{array}$ \\
\hline \multicolumn{3}{|c|}{ Fish and Wildlife and Vegetation } \\
\hline \multicolumn{3}{|c|}{ Aquatic Wildlife } \\
\hline Fish & FISH & $\begin{array}{l}\text { - Any mention of fish, general or specific. } \\
\text { - Does not include a reference to fishing by itself, this is CREC. }\end{array}$ \\
\hline $\begin{array}{l}\text { Other } \\
\text { Aquatic }\end{array}$ & AQO & $\begin{array}{l}\text { - Any reference to aquatic animal life besides fish. Includes frogs, } \\
\text { amphibians. } \\
\text { - Does not include general reference to "wildlife" (that is WLO). }\end{array}$ \\
\hline \multicolumn{3}{|l|}{ Land Wildlife } \\
\hline Mammals & MAMM & $\begin{array}{l}\text { - Appreciation of any mammal wildlife in association with river or } \\
\text { stream ecosystems, either particular mammals or mention of } \\
\text { "mammals" in general. }\end{array}$ \\
\hline Birds & BRD & $\begin{array}{l}\text { - Any mention of bird wildlife in association with river or stream } \\
\text { ecosystems, either particular birds or "birds" in general. } \\
\text { - Includes birdsong references. }\end{array}$ \\
\hline \multicolumn{3}{|l|}{ Other Wildlife } \\
\hline $\begin{array}{l}\text { Other } \\
\text { Wildlife }\end{array}$ & WLO & $\begin{array}{l}\text { - Any other reference to land wildlife, i.e. reptiles like lizards, insects } \\
\text { like butterflies. Includes mention of animal "sign" or tracks. } \\
\text { - Includes any unspecific reference to "wildlife" or "animals" or } \\
\text { "fauna" of the river. }\end{array}$ \\
\hline
\end{tabular}




\begin{tabular}{|c|c|c|}
\hline \multicolumn{3}{|l|}{ Vegetation } \\
\hline Trees & TR & $\begin{array}{l}\text { - Any mention of trees or forest in particular, including shade, tree type, } \\
\text { tree size or height, old growth. } \\
\text { - Includes mention of logging, in either positive or negative sense. } \\
\text { Logging would also be coded as IND. } \\
\text { - Includes references to wood in channel (independent from } \\
\text { navigability issues). }\end{array}$ \\
\hline $\begin{array}{l}\text { Other } \\
\text { Vegetation }\end{array}$ & VEGO & $\begin{array}{l}\text { - Any other reference to vegetation either specific or unspecific. } \\
\text { References to "plants" or "brush" or edible berries etc. all go here. } \\
\text { - No domesticated plants, like crops. However, naturalized (growing } \\
\text { wild) plants would be coded. } \\
\text { - Includes references to algae. }\end{array}$ \\
\hline \multicolumn{3}{|c|}{ Overarching Codes for Fish, Wildlife, Vegetation } \\
\hline $\begin{array}{l}\text { Pristine, } \\
\text { Untouched }\end{array}$ & PRIS & $\begin{array}{l}\text { - Pristine, remote, untouched, wild, wilderness; something is valued } \\
\text { because of these qualities. To warrant a PRIS code it has to be } \\
\text { something besides a reference to "natural". Distinct from SUPP code. } \\
\text { - Something with "wilderness" in the name is not sufficient, the passage } \\
\text { has to have something about the idea or quality of wilderness, e.g. the } \\
\text { ideas listed above. }\end{array}$ \\
\hline $\begin{array}{l}\text { Unusual, } \\
\text { Unique }\end{array}$ & UNUS & $\begin{array}{l}\text { - Something described as unusual or unique or rare. Not just "special"; } \\
\text { uniqueness is only one type of specialness. }\end{array}$ \\
\hline $\begin{array}{l}\text { Endangered } \\
\text { Species }\end{array}$ & ENDG & - Any reference to endangered, threatened, at-risk, or extinct species. \\
\hline $\begin{array}{l}\text { Sensitive } \\
\text { Species }\end{array}$ & SENS & $\begin{array}{l}\text { - Not an endangered species issue: an issue of physiological changes, } \\
\text { i.e. mutations such as with frogs; lesions on fish; a disproportionate } \\
\text { number of females of a given species. }\end{array}$ \\
\hline Native species & NSPEC & $\begin{array}{l}\text { - Any reference to native or invasive or non-native or stocked or } \\
\text { hatchery species. } \\
\text { - For example "stocked fish" would be coded FISH and NSPEC. }\end{array}$ \\
\hline Biodiversity & BIOD & - Mention of biodiversity or diversity or richness. \\
\hline Nuisance & NUIS & $\begin{array}{l}\text { - Mention of a plant or animal in context as a nuisance or a danger for } \\
\text { any reason, except invasiveness which is covered by the NSPEC code } \\
\text { above. Examples are mussels that clog machinery, briars that hurt } \\
\text { passersby. } \\
\text { - Also code the plant or animal code that is causing the nuisance, e.g. } \\
\text { clogging mussels are coded NUIS and AQO. }\end{array}$ \\
\hline \multicolumn{3}{|l|}{ Channel } \\
\hline $\begin{array}{l}\text { Safety of } \\
\text { Navigation }\end{array}$ & SNAV & $\begin{array}{l}\text { - Not necessarily a reference to danger: any reference to navigability } \\
\text { for commercial or for recreational purposes, such as currents, class of } \\
\text { whitewater, depth, shoals, rocks in context of important features for } \\
\text { navigation. } \\
\text { - Do not automatically code SNAV along with mention of boating } \\
\text { (CREC) unless navigation issues are also discussed. }\end{array}$ \\
\hline Rocks & ROK & $\begin{array}{l}\text { - Any reference to natural rocks on bank or in channel not related to } \\
\text { navigation, i.e. many people skip rocks or collect rocks along rivers, }\end{array}$ \\
\hline
\end{tabular}




\begin{tabular}{|c|c|c|}
\hline & & $\begin{array}{l}\text { or enjoy seeing rock formations visible from or near rivers. } \\
\text { - Includes rocks mentioned as a means to an end, such as rock outcrops } \\
\text { provide habitat for fish. }\end{array}$ \\
\hline $\begin{array}{l}\text { Channel or } \\
\text { Watershed } \\
\text { Statistics }\end{array}$ & LAREA & $\begin{array}{l}\text { - River or watershed quantified statistics on length, distance, or area. } \\
\text { Such as the numeric size of the watershed or the numeric distance of } \\
\text { the river reach. } \\
\text { - Includes quantified statistics on lengths, distances, or area of sections. } \\
\text { - Does not include volume, which is QUANO. }\end{array}$ \\
\hline \multicolumn{3}{|r|}{ 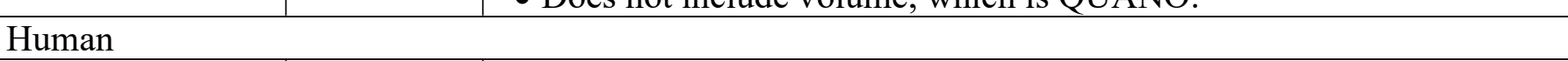 } \\
\hline Access & $\mathrm{ACC}$ & $\begin{array}{l}\text { - Interest in where is there legal OR physical public access to river } \\
\text { areas, or access to the water's edge itself. } \\
\text { - Commonly comes up in sense of there NOT being sufficient access. } \\
\text { For example, there are no public river parks near the Bronx. Or you } \\
\text { cannot kayak in Yellowstone. Or, there is a seawall in Portland, so } \\
\text { you can't get down to the water. } \\
\text { - Includes when the point is to express that a place is 'highly } \\
\text { accessible'. } \\
\text { - Could also be in the sense of not wanting people to illegally access the } \\
\text { river, to protect private property rights. } \\
\text { - Includes protecting private access or limiting access. }\end{array}$ \\
\hline $\begin{array}{l}\text { Negative } \\
\text { Infrastructure }\end{array}$ & NEGINF & $\begin{array}{l}\text { - Ugly human infrastructure or modifications to bank or channel. Be } \\
\text { sure things are described as ugly, not just your reaction. } \\
\text { - Includes references to appreciating that you cannot see any human } \\
\text { infrastructure or evidence of man. }\end{array}$ \\
\hline $\begin{array}{l}\text { Recreation } \\
\text { Amenities }\end{array}$ & RECAM & $\begin{array}{l}\text { - Positive or neutral reference to existing or desired recreation amenity } \\
\text { infrastructure including paths or trails, access roadway, a waterfront } \\
\text { park, signage, bathrooms, parking, safety features. If something is } \\
\text { mentioned in sense of overdeveloped it would go in NEGINF. } \\
\text { - All RECAM are access issues in a sense. Do not double-code with } \\
\text { ACC unless the paragraph is also stressing an access issue. }\end{array}$ \\
\hline $\begin{array}{l}\text { Maintenance } \\
\text { of Area }\end{array}$ & CARE & $\begin{array}{l}\text { - Reference to something well-maintained OR not well-maintained. } \\
\text { Litter, garbage, dilapidation go here. Graffiti or tagging goes here } \\
\text { unless described as a purposeful artistic component. } \\
\text { - Does not include something only referenced as "outdated" or } \\
\text { "obsolete" } \\
\text { - NOTE that we are under the "built environment" i.e. the HUMAN } \\
\text { subcategory of codes. Maintenance is distinct from intended purpose } \\
\text { or design or operations. For example, "careful' management for } \\
\text { environmental purposes is not the CARE code. }\end{array}$ \\
\hline
\end{tabular}




\begin{tabular}{|c|c|c|}
\hline Other Users & USENEG & $\begin{array}{l}\text { - Meant to cover fleeting impacts that only matter to other onsite } \\
\text { humans. Does not cover lasting impacts like infrastructure or litter or } \\
\text { ecosystem impacts, there are other codes for these issues. } \\
\text { - Examples: negative reference to other onsite users, such as } \\
\text { overcrowded, or potential safety from dangerous onsite users, or noise } \\
\text { from loud boats or partyers. Double code with type of recreational use } \\
\text { being described. } \\
\text { - Includes references to wanting solitude such as wanting not to even } \\
\text { see other users or other rec or commercial boats. }\end{array}$ \\
\hline
\end{tabular}

Code Family: Motivations

\begin{tabular}{|c|c|c|}
\hline $\begin{array}{l}\text { Code Meaning \& } \\
\text { Hierarchy }\end{array}$ & Code & Rule for Coding \\
\hline \multicolumn{3}{|l|}{ Consumptive Use } \\
\hline Agricultural & $\mathrm{AG}$ & $\begin{array}{l}\text { - Any reference to land-based agricultural use of rivers/streams, } \\
\text { including agricultural pollution. }\end{array}$ \\
\hline $\begin{array}{l}\text { Industrial \& } \\
\text { Commercial }\end{array}$ & IND & $\begin{array}{l}\text { - Any reference to industrial use of rivers/streams (besides Ag), } \\
\text { including commercial transport, commercial fishing, guided fishing, } \\
\text { fish farming, water for industrial processes, includes reference to } \\
\text { industrial pollution. } \\
\text { - Includes hydroelectricity. } \\
\text { - Includes forestry, timberlands references. } \\
\text { - Includes reference to economic impacts. }\end{array}$ \\
\hline Residential & RES & $\begin{array}{l}\text { - Any reference to residential, municipal, or domestic use of } \\
\text { rivers/streams for water supply or discharge. } \\
\text { - A dam being built to provide a source of drinking water would be } \\
\text { coded RES not IND. }\end{array}$ \\
\hline Tribal & TRIB & - Any reference to indigenous or tribal or native people. \\
\hline $\begin{array}{l}\text { Hunting or } \\
\text { Gathering }\end{array}$ & HUNT & $\begin{array}{l}\text { - Any reference to hunting anything along rivers and streams, including } \\
\text { animals, edible plants, or plants for crafts or boat-based. } \\
\text { - Also code what is being hunted, such as VEGO or MAMM or BRD. }\end{array}$ \\
\hline $\begin{array}{l}\text { Medicinal } \\
\text { Discoveries }\end{array}$ & MED & $\begin{array}{l}\text { - Preserve river and stream areas for medicinal benefits, known or } \\
\text { speculated from specific types of plants or animals. }\end{array}$ \\
\hline \multicolumn{3}{|c|}{ Non-Consumptive Use } \\
\hline $\begin{array}{l}\text { Water Contact } \\
\text { Recreation }\end{array}$ & CREC & $\begin{array}{l}\text { - Any reference to boating, swimming, wading, fishing along rivers and } \\
\text { streams. } \\
\text { - If a passage implies commercial fishing, do not code CREC. } \\
\text { - If a passage refers to commercial fishing guide (recreational fishing) } \\
\text { services this gets coded as both CREC and IND. }\end{array}$ \\
\hline $\begin{array}{l}\text { Passive } \\
\text { Outdoor } \\
\text { Recreation }\end{array}$ & PREC & $\begin{array}{l}\text { - Any reference to hiking, birdwatching, biking walking, viewing, } \\
\text { camping, or any unspecified tourism along rivers and streams. } \\
\text { Anything here could become CREC if contact with water is } \\
\text { mentioned. }\end{array}$ \\
\hline
\end{tabular}




\begin{tabular}{|c|c|c|}
\hline & & - Any unspecified "tourism" or "recreational use" is PREC by default. \\
\hline $\begin{array}{l}\text { Mental or } \\
\text { Emotional } \\
\text { Health }\end{array}$ & MENTAL & $\begin{array}{l}\text { - Not just exercise - this stresses mental or emotional health. } \\
\text { - Includes a desire to connect with nature. } \\
\text { - Meditation, spirituality, inspiration, de-stressing. }\end{array}$ \\
\hline \multicolumn{3}{|c|}{ Not Use Contingent } \\
\hline $\begin{array}{l}\text { Preserve for } \\
\text { Future }\end{array}$ & PRES & $\begin{array}{l}\text { - Wanting to preserve or conserve something ecological, such as for } \\
\text { future generations. A reference to preservation or to keeping } \\
\text { something for the future is needed for this code. }\end{array}$ \\
\hline $\begin{array}{l}\text { Rights of } \\
\text { Species }\end{array}$ & RIGHT & $\begin{array}{l}\text { - Right of a species, or any other anthropomorphized natural thing to } \\
\text { exist. It has as much right to exist as we do. }\end{array}$ \\
\hline $\begin{array}{l}\text { Nature's } \\
\text { Balance }\end{array}$ & NBAL & $\begin{array}{l}\text { - Everything has a purpose in the natural world. } \\
\text { - A disruption will reverberate through the natural system and affect } \\
\text { other natural features and/or humans. } \\
\text { - These passages need to demonstrate an understanding of the } \\
\text { interconnections of nature or how nature supports humans. } \\
\text { Something like "this river is overfished" is not an extensive enough } \\
\text { example of interconnections to qualify for this code. Cascading } \\
\text { impacts do qualify. } \\
\text { - Can come up with unintended consequences of introducing new } \\
\text { species that end up taking over; double code with NSPEC. } \\
\text { - Can come up with wanting to keep things "natural" to avoid unknown } \\
\text { consequences on humans if nature is degraded, double code with } \\
\text { SUPP. } \\
\text { - Includes abstract statements that things are connected to each other, } \\
\text { affecting each other. } \\
\text { - Not meant to capture specifically named one-off impacts, such as less } \\
\text { water means less fish. But less water means less fish means less birds } \\
\text { would qualify. Cascading impacts. }\end{array}$ \\
\hline $\begin{array}{l}\text { Human Greed } \\
\text { or Overuse }\end{array}$ & GREED & $\begin{array}{l}\text { - Reference to ecological problems being created by human needs that } \\
\text { are unfair or greedy. } \\
\text { - Reference to excessive consumption or excessive environmental or } \\
\text { carbon footprints go here. } \\
\text { - The key is that the passage conveys a sense of judgment. } \\
\text { - Does not cover issues between humans, i.e. the haves \& have-nots. }\end{array}$ \\
\hline Education & EDUC & $\begin{array}{l}\text { - Interest in educating others or interest in learning about any aspect of } \\
\text { rivers and streams, including water conservation and water footprint. } \\
\text { - Formal or informal education. Informally instilling values in children } \\
\text { still goes here. But not just any reference to kids swimming or } \\
\text { whatever, that is just another example of CREC. }\end{array}$ \\
\hline $\begin{array}{l}\text { Supposed to } \\
\mathrm{Be}\end{array}$ & SUPP & $\begin{array}{l}\text { - Explicit interest specifically in these ecological contexts: wanting to } \\
\text { keep, maintain, or restore what is "supposed to be"; OR what is } \\
\text { "natural". "Supposed to be" is in this case a reference to naturalness as } \\
\text { a preferred condition. } \\
\text { - For example, restoring to previous conditions, or referring to historic }\end{array}$ \\
\hline
\end{tabular}




\begin{tabular}{|c|c|c|}
\hline & & $\begin{array}{l}\text { conditions or status, or that things are getting worse from what they } \\
\text { used to be. } \\
\text { - Does not include just a reference that things are getting "worse" or } \\
\text { "better". Has to be somehow compared to how things were or should } \\
\text { naturally be. } \\
\text { - Includes an explicit reference that historic conditions should NOT be } \\
\text { the goal of river and stream conditions. For example, "there used to } \\
\text { be a lot of downed trees in the Willamette, which made it really } \\
\text { dangerous for boaters", this would be coded SUPP and SNAV. [Note: } \\
\text { there were no occurrences of SUPP in this latter sense.] }\end{array}$ \\
\hline $\begin{array}{l}\text { Self- } \\
\text { Sustaining }\end{array}$ & SELFS & $\begin{array}{l}\text { - Explicit interest in what ecosystem features could be self-sustaining, } \\
\text { i.e. without a lot of human intervention. For example someone may } \\
\text { mention invasive fish as preferable because they don't require } \\
\text { restocking. This passage would be coded FISH, NSPEC, and SELFS. } \\
\text { - Reference to an impediment to self-sustaining also qualifies. } \\
\text { - Reference to water depletion solely in context to human use does not } \\
\text { fall under this category. This must include an ecological attribute. } \\
\text { - Be careful of "Sustainability" references which may or may not fit } \\
\text { here. "Sustainability" all by itself might be too vague to fit anywhere. }\end{array}$ \\
\hline
\end{tabular}

Code Family: Other

\begin{tabular}{|l|l|l|}
\hline $\begin{array}{l}\text { Code Meaning \& } \\
\text { Hierarchy }\end{array}$ & Code & Rule for Coding \\
\hline $\begin{array}{l}\text { No code present } \\
\text { in paragraph }\end{array}$ & NOCODE & $\begin{array}{l}\bullet \text { Code applied to any paragraph that was not coded with any other } \\
\text { codes. }\end{array}$ \\
\hline
\end{tabular}


Appendix 2: Alphabetical Code examples and subthemes. Additional codes applying to each example paragraph are suppressed. For long form description of codes, see Appendix 1.

\begin{tabular}{|c|c|c|}
\hline $\begin{array}{l}\text { Code } \\
\text { Shorthand }\end{array}$ & Sample Paragraph & $\begin{array}{l}\text { Common Subthemes Within } \\
\text { Code }\end{array}$ \\
\hline ACC & $\begin{array}{l}\text { During my investigative journey in the headwaters, a } \\
\text { rancher who believes (like many other Coloradoans) that he } \\
\text { owns the river, tried to have me arrested for trespassing in } \\
\text { my tiny raft. That section of the river in fact is sometimes } \\
\text { drained to steam size by diversions to distant Denver. } \\
\text { - Blog }\end{array}$ & $\begin{array}{l}\text { Private and public } \\
\text { regulation of access, } \\
\text { including ideas of } \\
\text { ownership and safety. }\end{array}$ \\
\hline AG & $\begin{array}{l}\text { If ultimately enacted, the plans would open a 300-plus-mile } \\
\text { migratory route to spawning grounds for endangered } \\
\text { Pacific salmon. The agreements also cover the distribution } \\
\text { of Klamath Basin water between farmers and ecosystems } \\
\text { that support both fish and the fishermen who catch them. } \\
\text { Dispute over the fate of the Klamath's water dates back a } \\
\text { century. } \\
\text { - Blog }\end{array}$ & $\begin{array}{l}\text { Water footprint of } \\
\text { agriculture; floodplain } \\
\text { agriculture; legislation and } \\
\text { economic aspects of } \\
\text { agriculture; impacts of } \\
\text { floods on agriculture; } \\
\text { economic impacts to } \\
\text { agriculture. }\end{array}$ \\
\hline $\mathrm{AQO}$ & $\begin{array}{l}\text { The most optimistic here even see the influx of fresh, sweet } \\
\text { river water as a good thing for the swamp, even though it is } \\
\text { likely to hurt oyster beds and shrimping grounds along the } \\
\text { gulf shore. The wild crawfish will come strong in future } \\
\text { seasons. The fish will be more plentiful. } \\
\text { - NYT }\end{array}$ & $\begin{array}{l}\text { Thematic articles } \\
\text { highlighting specific } \\
\text { species; specific species as } \\
\text { part of discussion of broader } \\
\text { ecosystem. }\end{array}$ \\
\hline BIOD & $\begin{array}{l}\text { Today } 69 \text { percent of U.S. freshwater mussel species are to } \\
\text { some degree at risk of extinction or already extinct. The } \\
\text { most diverse assemblage of freshwater mussels ever known } \\
\text { was located in the middle stretch of the Tennessee River in } \\
\text { northern Alabama. Before the damming of the river in the } \\
\text { early } 1900 \text { s, } 69 \text { mussel species had been spotted in this } \\
\text { reach; } 32 \text { of them have apparently disappeared, with no } \\
\text { recording sightings in nearly a century. - Blog }\end{array}$ & $\begin{array}{l}\text { Current and past } \\
\text { (bio)diversity, including } \\
\text { concern over lost diversity. }\end{array}$ \\
\hline BRD & $\begin{array}{l}\text { In fact, a few years before Ms. Hardie, who is } 57 \text { years old, } \\
\text { and her husband Frank, } 62 \text {, moved to Charleston in } 2008 \text {, } \\
\text { they bought a two-bedroom condo facing the Cooper River. } \\
\text { Now they enjoy being a few blocks from the downtown } \\
\text { hubbub while also being able to watch porpoises and herons } \\
\text { from their porch. } \\
\text { - WSJ }\end{array}$ & $\begin{array}{l}\text { General and specific } \\
\text { references to birds, } \\
\text { including birdwatching and } \\
\text { their role in the ecosystem, } \\
\text { birdwatching. }\end{array}$ \\
\hline CARE & $\begin{array}{l}\text { On a recent day, a tugboat passed through the Charleroi } \\
\text { Locks along the Monongahela River in Pennsylvania. Only } \\
\text { one lock is working and its gate is anchored in crumbling } \\
\text { concrete. } \\
\text { - WSJ }\end{array}$ & $\begin{array}{l}\text { Litter, aging and poorly } \\
\text { maintained infrastructure. }\end{array}$ \\
\hline
\end{tabular}




\begin{tabular}{|c|c|c|}
\hline CHR & $\begin{array}{l}\text { Today a viscous rainbow sheen floats on its surface, and the } \\
\text { area around it is redolent of hydrocarbons. Although } \\
\text { Greenpoint has a lower overall cancer rate than much of the } \\
\text { city, it has one of the highest incidences of certain cancers, } \\
\text { like leukemia in children and stomach cancer in adults. The } \\
\text { creek was designated a Superfund site in } 2009 \text {. } \\
-N Y T\end{array}$ & $\begin{array}{l}\text { Health concerns from } \\
\text { contaminated/dirty water, } \\
\text { explicit sewage } \\
\text { contamination. }\end{array}$ \\
\hline CLAR & $\begin{array}{l}\text { Oregon's Chetco River is one example. The river's gin-clear } \\
\text { waters teem with wild trout and salmon, including giant } \\
\text { Chinook salmon tipping scales at more than } 60 \text { pounds. In } \\
\text { 1988, Congress designated the Chetco a national wild and } \\
\text { scenic river "to be protected for the benefit of present and } \\
\text { future generations." } \\
-N Y T\end{array}$ & $\begin{array}{l}\text { Judgment calls on color of } \\
\text { water, both clear and not } \\
\text { clear, general reference to } \\
\text { color of water caused by } \\
\text { things in it. }\end{array}$ \\
\hline CREC & $\begin{array}{l}\text { For fly fishers who pride themselves on a conservationist } \\
\text { ethic, it hurts to discover that they may be trampling on that } \\
\text { ethic every time they wade into a trout stream. } \\
-N Y T\end{array}$ & $\begin{array}{l}\text { General and specific } \\
\text { references, especially } \\
\text { boating, fishing, and } \\
\text { swimming. }\end{array}$ \\
\hline$\overline{E D U C}$ & $\begin{array}{l}\text { Wildlife biologists and local and national fishing groups } \\
\text { like Trout Unlimited have spread the word about the threat } \\
\text { of didymo and felt. On fishing blogs, anglers persistently } \\
\text { debate the merits and drawbacks of the new rubber soles } \\
\text { and the felt bans approved this spring by Vermont's } \\
\text { Legislature and Alaska's Board of Fisheries. (Vermont's ban } \\
\text { takes effect next April and Alaska's in January 2012.) } \\
\text { - NYT }\end{array}$ & $\begin{array}{l}\text { Informal education on water } \\
\text { usage, education and } \\
\text { awareness, formal research. }\end{array}$ \\
\hline ENDG & $\begin{array}{l}\text { The Gila (pronounced Heela) spotlights what a river can be } \\
\text { when it flows not according to human demands for water } \\
\text { and energy but rather to Natures time-tested rhythms. Its } \\
\text { seasonal highs and lows and gentle meanders across a broad } \\
\text { floodplain create a rich mosaic of habitats that are home to } \\
\text { a splendorous array of life including some } 280 \text { species of } \\
\text { birds. Among them are the rare western yellow-billed } \\
\text { cuckoo, the Mexican spotted owl and perhaps the largest } \\
\text { population anywhere of the endangered southwestern } \\
\text { willow flycatcher, which fancies the gracious Goodding } \\
\text { willows that shade the Gilas banks. } \\
\text { - Blog }\end{array}$ & $\begin{array}{l}\text { Local or regionally } \\
\text { vulnerable species, species } \\
\text { at risk of complete } \\
\text { extinction. }\end{array}$ \\
\hline FD & $\begin{array}{l}\text { What is needed is a comprehensive plan to add ecological } \\
\text { infrastructure to complement engineering infrastructure - } \\
\text { specifically to expand wetlands and re-activate floodplains } \\
\text { so as to mitigate future flood risks. } \\
\text { - Blog }\end{array}$ & $\begin{array}{l}\text { The Blog especially } \\
\text { emphasizes the role of } \\
\text { wetlands and the } \\
\text { environment in flooding, } \\
\text { especially how nature alters } \\
\text { flood risk. Perhaps due to } \\
\text { major flooding of the } \\
\text { Mississippi during the }\end{array}$ \\
\hline
\end{tabular}




\begin{tabular}{|c|c|c|}
\hline & & $\begin{array}{l}\text { sample period, the } \\
\text { NYT/WSJ especially } \\
\text { focused on actual damages } \\
\text { and flood control decision- } \\
\text { making. }\end{array}$ \\
\hline FHZ & $\begin{array}{l}\text { Unfortunately we're likely to see more breached, failed and } \\
\text { overtopped levees in the future, because for several reasons, } \\
\text { the deck is increasingly being stacked against the } \\
\text { Mississippi's levees being able to provide the protection of } \\
\text { life and property they once did. } \\
\text { - Blog }\end{array}$ & $\begin{array}{l}\text { The Blog emphasizes broad } \\
\text { information on public } \\
\text { safety, while the NYT/WSJ } \\
\text { focus more on specific } \\
\text { occurrences, including } \\
\text { references to evacuation and } \\
\text { deaths. }\end{array}$ \\
\hline FISH & $\begin{array}{l}\text { Six Great Lakes states and the Canadian province of } \\
\text { Ontario have petitioned the U.S. Supreme Court to separate } \\
\text { the water basins in a last-ditch effort to prevent the Asian } \\
\text { carp from decimating the } \$ 7 \text { billion Great Lakes fishing } \\
\text { industry. The Army Corps of Engineers has launched a } \$ 10 \\
\text { million, five-year feasibility study of the idea. And the plan } \\
\text { became the focus of a hearing on the Asian carp problem on } \\
\text { Capitol Hill last week. } \\
\text { - WSJ }\end{array}$ & $\begin{array}{l}\text { Invasiveness, human } \\
\text { impacts on fish populations, } \\
\text { fisheries, and fish as part of } \\
\text { the ecosystem. }\end{array}$ \\
\hline $\mathrm{FO}$ & $\begin{array}{l}\text { The great lesson of the floods may be that humans will have } \\
\text { to do a lot more if they are to outwit nature, if that is even } \\
\text { possible. } \\
-N Y T\end{array}$ & $\begin{array}{l}\text { The Blog focuses on } \\
\text { flooding as a natural } \\
\text { occurrence, including the } \\
\text { use of floodplains in flood } \\
\text { management and flooding } \\
\text { restoring wetlands. The } \\
\text { NYT/WSJ focus more on } \\
\text { human interactions with } \\
\text { flooding, including } \\
\text { engineering solutions for } \\
\text { flood management. }\end{array}$ \\
\hline GREED & $\begin{array}{l}\text { "It's all about the almighty buck," Mr. Boyd said. "It's the } \\
\text { destruction of Mother Earth and the life blood of the river } \\
\text { for money." } \\
\text { - NYT }\end{array}$ & $\begin{array}{l}\text { Disregard for nature, } \\
\text { ineffective legislation } \\
\text { (underregulated, } \\
\text { underfunded, or too limited } \\
\text { in application), human } \\
\text { interests (including } \\
\text { development) versus nature. }\end{array}$ \\
\hline HUNT & $\begin{array}{l}\text { He and others waiting for the floodwaters make a point of } \\
\text { saying that the heart of Cajun country here will be just fine. } \\
\text { Zydeco music will still spill from the cafes in nearby } \\
\text { Breaux Bridge, and the last of the crawfish from this season } \\
\text { will continue to be boiled in countless backyards. } \\
\text { - NYT }\end{array}$ & $\begin{array}{l}\text { Using river-related fauna as } \\
\text { a food source (excluding } \\
\text { fish). }\end{array}$ \\
\hline IND & In a normal year, the water that is used to keep the river & Complex code covering \\
\hline
\end{tabular}




\begin{tabular}{|c|c|c|}
\hline & $\begin{array}{l}\text { level high enough for barges comes from releases from the } \\
\text { dam system built to control river flow. But the states north } \\
\text { of the dams, including North and South Dakota, have } \\
\text { argued that the river is no longer needed for navigation and } \\
\text { that more water should be kept in the reservoirs for } \\
\text { recreation, to help the region's economy. } \\
- \text { NYT }\end{array}$ & $\begin{array}{l}\text { topics such as } \\
\text { pollution/contamination } \\
\text { from private entities, } \\
\text { shipping, commercial } \\
\text { fishing, energy production, } \\
\text { water-based businesses (e.g. } \\
\text { kayak rental), etc. }\end{array}$ \\
\hline LAREA & $\begin{array}{l}\text { The study, issued by the environmental group Riverkeeper, } \\
\text { underscores how a big sewage discharge in July, caused by } \\
\text { a fire at a treatment plant in Manhattan, was part of a } \\
\text { persistent and far more widespread sewage problem along } \\
\text { the } 155 \text {-mile river. } \\
- \text { NYT }\end{array}$ & $\begin{array}{l}\text { The Blog tended to } \\
\text { reference area, while the } \\
\text { NYT/WSJ tended to } \\
\text { reference length. }\end{array}$ \\
\hline MAMM & $\begin{array}{l}\text { In } 2007 \text {, a beaver, a species driven out of New York waters } \\
200 \text { years ago by overeager fur traders and developers, was } \\
\text { seen in the river, and its } 12 \text {-foot wide lodge -- a mound of } \\
\text { twigs and mud -- was discovered. The beaver was } \\
\text { christened Jose in honor of Mr. Serrano. } \\
- \text { NYT }\end{array}$ & $\begin{array}{l}\text { Specific references to a } \\
\text { variety of mammalian } \\
\text { species. }\end{array}$ \\
\hline MENTAL & $\begin{array}{l}\text { "At the time I started there were no public access points to } \\
\text { the water," he remembered. "I could come here to this place } \\
\text { of peace and tranquility amid this chaos of New York City. } \\
\text { You feel you're losing something genuine. On the other } \\
\text { hand, my images have taken on deeper meaning as historic } \\
\text { documents." } \\
\text { - WSJ }\end{array}$ & $\begin{array}{l}\text { Getting away from the } \\
\text { chaos of the city and a } \\
\text { positive aspect to being } \\
\text { immersed in nature. }\end{array}$ \\
\hline MVMT & $\begin{array}{l}\text { In the background was the music of the Gilas riffles, where } \\
\text { the river bubbles over cobbles in its bed, adding oxygen to } \\
\text { the water. It was a sensory feast the sights and sounds of the } \\
\text { Gila, alive. } \\
\text { - Blog }\end{array}$ & $\begin{array}{l}\text { Movement suggesting a } \\
\text { river is alive, river speed. }\end{array}$ \\
\hline NBAL & $\begin{array}{l}\text { Such changes can begin to unravel a whole web of life, } \\
\text { which in turn can eliminate crucial services we humans get } \\
\text { from healthy rivers and streams including the purification } \\
\text { of our drinking water. For example, many freshwater } \\
\text { mussels disperse by hitching a ride with a particular species } \\
\text { of fish before dropping off and nestling into a streambed. If } \\
\text { that fish disappears from the river, so may the mussels. } \\
\text { That's bad news for water quality as a single mussel can } \\
\text { filter up to a gallon of water per hour. } \\
\text { - Blog }\end{array}$ & $\begin{array}{l}\text { Human modifications } \\
\text { impacting species and river } \\
\text { systems, invasive species } \\
\text { damaging ecosystems, } \\
\text { broad interconnections and } \\
\text { cycles. }\end{array}$ \\
\hline NEGINF & $\begin{array}{l}\text { As they stood on the bank, the small and eager group } \\
\text { exchanged the requisite disparaging jokes about the Los } \\
\text { Angeles River, best known for its uninviting concrete } \\
\text { channels that make many think of a drainage ditch. } \\
\text { - NYT }\end{array}$ & $\begin{array}{l}\text { Hope for the removal of } \\
\text { infrastructure, criticism of } \\
\text { the normalcy of concrete } \\
\text { channels, criticism of } \\
\text { adding infrastructure. }\end{array}$ \\
\hline
\end{tabular}




\begin{tabular}{|c|c|c|}
\hline NOCODE & $\begin{array}{l}\text { It felt like Death Valley as stifling heat reached down on } \\
\text { Friday and took the city in its clammy grip, transforming } \\
\text { the streets and sidewalks into hot griddles and creating } \\
\text { instant dripping wretchedness. } \\
\text { - NYT }\end{array}$ & $\begin{array}{l}\text { Applied to any paragraph } \\
\text { that was not otherwise } \\
\text { coded. }\end{array}$ \\
\hline NSPEC & $\begin{array}{l}\text { A single-celled organism also known as rock snot, didymo } \\
\text { has done as much as any invasive species to prompt calls } \\
\text { for a ban on felt soles. } \\
-N Y T\end{array}$ & $\begin{array}{l}\text { General reference to native } \\
\text { species, humans causing } \\
\text { introduction of invasive } \\
\text { species or making native } \\
\text { species vulnerable. }\end{array}$ \\
\hline NUIS & $\begin{array}{l}\text { Asian carp have few natural predators and can grow up to } \\
\text { four feet long and weigh } 100 \text { pounds. They reproduce } \\
\text { several times a year and outcompete native fish for food. To } \\
\text { make matters worse, they blindly leap up to eight feet out of } \\
\text { the water at the whining sound of high-speed propellers, } \\
\text { injuring boaters. } \\
\text { - WSJ }\end{array}$ & $\begin{array}{l}\text { Fish injuring humans, toxic } \\
\text { plants, dead zones caused } \\
\text { by algae. }\end{array}$ \\
\hline ODOR & $\begin{array}{l}\text { "To me it was always about getting access," Mr. Hamboussi } \\
\text { explained. It apparently still is. Our final stop -- though the } \\
\text { photographer was clearly just getting warmed up a couple } \\
\text { of hours into our tour of his old stomping grounds -- was } \\
\text { the remnants of the Maspeth Bridge, these days little more } \\
\text { than some ancient wooden sticks jutting from the fetid } \\
\text { waters. } \\
- \text { WSJ }\end{array}$ & Unpleasant odors. \\
\hline PREC & $\begin{array}{l}\text { Suzanne Hardie found herself drawn to Charleston, S.C., } \\
\text { and its pedestrian-friendly, antebellum waterfront after } \\
\text { wrapping up her chemical-engineering career with Procter } \\
\& \text { Gamble Co. She had been living in a small German city, } \\
\text { where she walked everywhere and enjoyed the historical } \\
\text { charm. } \\
\text { - WSJ }\end{array}$ & $\begin{array}{l}\text { Various ways, including } \\
\text { walking/walking paths, river } \\
\text { as viewscape, rivers as part } \\
\text { of artistic endeavors, and } \\
\text { tourism. }\end{array}$ \\
\hline PRES & $\begin{array}{l}\text { Just as we buy home insurance and life insurance to protect } \\
\text { ourselves and our families from catastrophic losses, so } \\
\text { society now needs to buy disaster insurance to reduce the } \\
\text { damage caused by floods and other weather related events. } \\
\text { By strategically investing in the protection and restoration } \\
\text { of ecological infrastructure, we can begin to re-gain the } \\
\text { benefits of nature's services. } \\
\text { - Blog }\end{array}$ & $\begin{array}{l}\text { Preservation for the } \\
\text { immediate future, } \\
\text { preservation for future } \\
\text { generations, preserving or } \\
\text { protecting species, } \\
\text { protecting rivers. }\end{array}$ \\
\hline PRIS & $\begin{array}{l}\text { Opponents say the loads will change the wild character of } \\
\text { the rivers, as floaters fish and watch giant machinery go by. } \\
\text { - NYT }\end{array}$ & $\begin{array}{l}\text { Wilderness untouched by } \\
\text { man, general idea of } \\
\text { wild/wilderness, untouched } \\
\text { scenery. }\end{array}$ \\
\hline QUALO & $\begin{array}{l}\text { In today's economy, job creation trumps just about } \\
\text { everything. But for Nebraskans, at least one thing ranks }\end{array}$ & $\begin{array}{l}\text { The Blog tends to talk about } \\
\text { water quality in abstract }\end{array}$ \\
\hline
\end{tabular}




\begin{tabular}{|c|c|c|}
\hline & $\begin{array}{l}\text { higher and that's protecting their precious water sources. } \\
\text { They know, as we all should, that ample clean water is } \\
\text { crucial for economic vitality now and for generations to } \\
\text { come. } \\
\text { - Blog }\end{array}$ & $\begin{array}{l}\text { terms. The NYT especially } \\
\text { focuses on formal analysis } \\
\text { and regulation of water } \\
\text { quality, often in connection } \\
\text { with drinking water. The } \\
\text { WSJ especially focuses on } \\
\text { negative water quality. }\end{array}$ \\
\hline QUALSP & $\begin{array}{l}\text { In } 2007, \text { for instance, after a pipe manufacturer in Alabama, } \\
\text { a division of McWane Inc., was convicted and fined } \\
\text { millions of dollars for dumping oil, lead, zinc and other } \\
\text { chemicals into a large creek, an appellate court overturned } \\
\text { that conviction and fine, ruling that the Supreme Court } \\
\text { precedent exempted the waterway from the Clean Water } \\
\text { Act. The company eventually settled by agreeing to pay a } \\
\text { smaller amount and submit to probation. } \\
-N Y T\end{array}$ & $\begin{array}{l}\text { Many attributes, including } \\
\text { temperature, salinity, } \\
\text { bacteria, chemicals, heavy } \\
\text { metals, etc. }\end{array}$ \\
\hline QUANO & $\begin{array}{l}\text { What ecologist Daren Carlisle and his colleagues found is } \\
\text { nothing short of a wake-up call to make the restoration of } \\
\text { river flows a high priority. Flows were altered in nearly } \\
\text { nine in ten river segments, and compared with eight other } \\
\text { variables including water temperature, nitrogen and } \\
\text { phosphorus pollution, and the loss of riverside land to } \\
\text { farming or urban uses stream-flow alteration was the } \\
\text { primary predictor of a rivers biological integrity. } \\
\text { - Blog }\end{array}$ & $\begin{array}{l}\text { Flows and flow levels, } \\
\text { implied volume, river } \\
\text { heights. }\end{array}$ \\
\hline RECAM & $\begin{array}{l}\text { Four miles and about } 90 \text { minutes later, we arrived at Ferry } \\
\text { Swale, one of six sandy campsites, each with a composting } \\
\text { toilet, maintained by the Park Service. With all of our many } \\
\text { imported comforts, this was five-star camping. After setting } \\
\text { up our tents and cooking dinner, there was blissfully little to } \\
\text { do but watch hundreds of stars glimmer into view as night } \\
\text { fell. Later the moon arrived, bathing the cliffs in a surreal } \\
\text { silvery glow. } \\
\text { - NYT }\end{array}$ & $\begin{array}{l}\text { Specific and general } \\
\text { amenities, including parks, } \\
\text { beaches, boat launches, and } \\
\text { campgrounds. }\end{array}$ \\
\hline RES & $\begin{array}{l}\text { Who would believe that a translucent sightless amphibian } \\
\text { that dwells only in dark underground caves could force a } \\
\text { big Texas city to not only slash its water use but make } \\
\text { water waste illegal? But the rare, four-inch Texas blind } \\
\text { salamander has done pretty much just that and spawned an } \\
\text { unusual water story in San Antonio, where impressive } \\
\text { conservation efforts are now being tested by one of the } \\
\text { worst droughts in memory. } \\
\text { - Blog }\end{array}$ & $\begin{array}{l}\text { Several facets of residential } \\
\text { use of or discharge into } \\
\text { river water, including } \\
\text { drinking water, } \\
\text { contamination via flushing, } \\
\text { sewage treatment plants, } \\
\text { and competing interests. }\end{array}$ \\
\hline ROK & $\begin{array}{l}\text { To the south, flash floods out of Peralta Canyon had left a } \\
\text { wide trail of boulders, black mud, and charred debris. They } \\
\text { had also deposited ten feet of sediment in the channel, }\end{array}$ & $\begin{array}{l}\text { Rocks or gravel beds, rocks } \\
\text { on water's edge, boulders } \\
\text { moved by floods, impact of }\end{array}$ \\
\hline
\end{tabular}




\begin{tabular}{|c|c|c|}
\hline & $\begin{array}{l}\text { which will raise the level of subsequent floods. } \\
- \text { Blog }\end{array}$ & mining. \\
\hline SELFS & $\begin{array}{l}\text { Despite these challenges, self-sustaining populations of } \\
\text { large-bodied catfish still exist. Globally, efforts to protect } \\
\text { the ecological integrity of rivers where large-bodied catfish } \\
\text { occur will benefit thousands of species of freshwater fish } \\
\text { and millions of people who rely on fish for their livelihoods } \\
\text { and food security. Plus, they're cute! } \\
\text { - Blog }\end{array}$ & $\begin{array}{l}\text { Impact of human or lack of } \\
\text { human intervention, } \\
\text { sustainable species and } \\
\text { ecosystems, sustainable } \\
\text { water usage. }\end{array}$ \\
\hline SENS & $\begin{array}{l}\text { The U.S. Geological Survey (USGS) started to detect this } \\
\text { [sic] chemicals in rivers throughout the U.S. nearly ten } \\
\text { years ago, and then in } 2003 \text { intersex fish were collected } \\
\text { from several Potomac River sites. } \\
\text { - Blog }\end{array}$ & $\begin{array}{l}\text { Impacts of endocrine } \\
\text { disruptors on fish } \\
\text { populations. }\end{array}$ \\
\hline SEW & $\begin{array}{l}\text { The announcement came eight days after a four-alarm fire } \\
\text { at the North River Wastewater Treatment Plant in Harlem } \\
\text { led to the discharge of hundreds of millions of gallons of } \\
\text { untreated sewage into the Hudson River. } \\
- \text { - NYT }\end{array}$ & $\begin{array}{l}\text { References to sewage } \\
\text { treatment plants or treated } \\
\text { wastewater. }\end{array}$ \\
\hline SHZ & $\begin{array}{l}\text { This year, there have been seven drownings in unguarded } \\
\text { New York City waters, health department officials said. } \\
\text { There have been no deaths in places where lifeguards have } \\
\text { been present, they said. } \\
\text { - NYT }\end{array}$ & $\begin{array}{l}\text { Recreational swimming and } \\
\text { drowning, forbidden access, } \\
\text { injury from slipping, } \\
\text { potential danger of } \\
\text { drowning while kayaking. }\end{array}$ \\
\hline SNAV & $\begin{array}{l}\text { But the Missouri can accommodate fewer barges because of } \\
\text { the strong current and sharper bends. And though } \\
\text { navigation, along with flood control, gets priority for } \\
\text { releases of water from dams, the unpredictable river levels } \\
\text { have made shipping contracts riskier. } \\
- \text { NYT }\end{array}$ & $\begin{array}{l}\text { River engineering for } \\
\text { commercial traffic, } \\
\text { dangerous waterways, } \\
\text { defining navigability in } \\
\text { regards to regulation, } \\
\text { recreational navigation. }\end{array}$ \\
\hline SND & $\begin{array}{l}\text { It is New York City's only freshwater river, a gurgling, } \\
\text { meandering relic of the pastoral terrain that almost } 400 \\
\text { years ago beguiled early European explorers and traders. } \\
-N Y T\end{array}$ & $\begin{array}{l}\text { Used as a descriptor of a } \\
\text { setting. }\end{array}$ \\
\hline SUPP & $\begin{array}{l}\text { It's important to note that bringing a damaged stream back } \\
\text { to life is not an easy process; it takes time and can be } \\
\text { fraught with challenges. But if an appropriate plan is put in } \\
\text { place and adhered to over time, things can be turned around } \\
\text { for virtually any waterway. } \\
\text { - Blog }\end{array}$ & $\begin{array}{l}\text { The Blog especially } \\
\text { emphasizes what should be } \\
\text { done to existing conditions. } \\
\text { The NYT/WSJ discuss a } \\
\text { wide variety of examples, } \\
\text { including what is considered } \\
\text { natural, the role of man } \\
\text { within nature, and historical } \\
\text { conditions. }\end{array}$ \\
\hline TR & $\begin{array}{l}\text { So much riparian restoration is about planting trees, but } \\
\text { here the river is healing itself, said Martha S. Cooper, a } \\
\text { forest ecologist and Southwest New Mexico Field }\end{array}$ & $\begin{array}{l}\text { Forest management, forest } \\
\text { fires, trees in relation to } \\
\text { flooding, trees along }\end{array}$ \\
\hline
\end{tabular}




\begin{tabular}{|c|c|c|}
\hline & $\begin{array}{l}\text { Representative with The Nature Conservancy. The Gila still } \\
\text { has its hydrograph. The floods still have the power to act } \\
\text { creatively on the landscape. } \\
\text { - Blog }\end{array}$ & riverbanks. \\
\hline TRIB & $\begin{array}{l}\text { In the case of the Klamath, it's a great example of how } \\
\text { various uses for the river came into conflict: Native } \\
\text { American interests, fisheries interests, farmers' interests, } \\
\text { the desire for hydroelectric power. And then there were the } \\
\text { beautiful salmon runs. The four dams slated to come down } \\
\text { under these agreements brought all the conflicts over waters } \\
\text { uses to a head. } \\
\text { - Blog }\end{array}$ & $\begin{array}{l}\text { Pre-Columbian and } \\
\text { historical tribal use of } \\
\text { rivers, tribal stakeholders in } \\
\text { planning, impacts of } \\
\text { flooding and scarcity on } \\
\text { native people. }\end{array}$ \\
\hline UNUS & $\begin{array}{l}\text { My favorite freshwater mussel is the orange-nacre mucket } \\
\text { (Lampsilis perovalis), found only in the rivers and streams } \\
\text { of Alabama's Mobile River basin. Like many freshwater } \\
\text { mussels, the orange-nacre mucket has a fascinating life } \\
\text { cycle and exhibits some of the most sophisticated mimicry } \\
\text { in the animal kingdom. } \\
\text { - Blog }\end{array}$ & $\begin{array}{l}\text { Unique or unusual } \\
\text { animals/animal behavior, } \\
\text { unique to a location, unique } \\
\text { landscapes. }\end{array}$ \\
\hline USENEG & $\begin{array}{l}\text { Water levels fluctuate year to year, depending on rainfall } \\
\text { and dam releases. This spring -- good news for kayakers-- } \\
\text { the river is higher than it's been in the recent past. But even } \\
\text { when levels are low in the park, there is the Lower Canyons } \\
\text { area, a spring-fed stretch of the river that runs for } 83 \text { remote } \\
\text { miles beyond the park's eastern boundary. Here, you are } \\
\text { almost guaranteed not to see another soul. } \\
\text { - NYT }\end{array}$ & $\begin{array}{l}\text { Appreciation of minimal } \\
\text { exposure to others using the } \\
\text { river, criticizing tourist use } \\
\text { of the river. }\end{array}$ \\
\hline VEGO & $\begin{array}{l}\text { While large scale improvements didn't happen overnight, } \\
\text { staff and students did make steady progress year-in and } \\
\text { year-out; slowly, the creek started to show signs of life. } \\
\text { Streamside vegetation was eventually restored, in-stream } \\
\text { habitat improved, and water quality issues addressed. } \\
\text { Finally, several years ago, the stream had improved to the } \\
\text { point where we could re-establish a trout population for the } \\
\text { first time in almost four decades. } \\
\text { - Blog }\end{array}$ & $\begin{array}{l}\text { Streamside vegetation, } \\
\text { aquatic plants, native plants } \\
\text { and shrubs, grasslands. }\end{array}$ \\
\hline WLO & $\begin{array}{l}\text { But the river is once again at risk. Over the last twenty-five } \\
\text { years, tireless advocates have blocked the construction of } \\
\text { two dams. Today, the threat is a proposed diversion to } \\
\text { siphon off } 14,000 \text { acre-feet of water per year. By skimming } \\
\text { peaks off of modest floods, and piping the water some } 25 \\
\text { miles to an off-channel reservoir, the project would weaken } \\
\text { the rivers critical connection to its floodplain and the } \\
\text { galleries of cottonwoods and willows that provide the } \\
\text { habitat so crucial to the areas rich diversity of birds and } \\
\text { wildlife. }\end{array}$ & $\begin{array}{l}\text { General references to } \\
\text { wildlife and discussion of } \\
\text { specific species. }\end{array}$ \\
\hline
\end{tabular}




\begin{tabular}{|l|l|l|}
\hline & - Blog & \\
\hline WSHR & $\begin{array}{l}\text { Up to } 80 \text { percent of this residue containing arsenic, } \\
\text { cadmium, and other contaminants associated with cancer is } \\
\text { dumped into landfills. These toxins have been known to } \\
\text { leach into groundwater supplies near dumpsites. } \\
- \text { Blog }\end{array}$ & $\begin{array}{l}\text { Water contamination, } \\
\text { monitoring of water, need to } \\
\text { secure clean water, linking } \\
\text { chemicals/contaminants to } \\
\text { health risks. }\end{array}$ \\
\hline WSS & $\begin{array}{l}\text { As individuals, we can make a start. But to keep rivers } \\
\text { flowing and ecosystems healthy will also take the efforts of } \\
\text { corporations, dam managers, energy and water providers, } \\
\text { and many others. Together, a societal goal of shrinking our } \\
\text { collective water footprint by 25 percent by 2025 is within } \\
\text { reach. Water is life. Let's share it. } \\
- \text { - Blog }\end{array}$ & $\begin{array}{l}\text { The Blog focuses on a } \\
\text { proactive approach of } \\
\text { reacting to and planning for } \\
\text { scarcity, while the } \\
\text { NYT/WSJ focus more on } \\
\text { dealing with drought and } \\
\text { controlling a limited } \\
\text { resource. }\end{array}$ \\
\hline
\end{tabular}


Appendix 3: Article titles and brief summary.

\begin{tabular}{|c|c|c|c|}
\hline Article & Source & Title & Summary \\
\hline 1 & Blog & $\begin{array}{l}\text { Clean Energy the } \\
\text { Solution to Western } \\
\text { U.S. Water Woes }\end{array}$ & $\begin{array}{l}\text { This article discusses a Western Resource Advocates report on } \\
\text { the water footprint of various energy sources, emphasizing } \\
\text { how water-intensive coal plants are, while clean renewable } \\
\text { sources may use very little water during operation. }\end{array}$ \\
\hline 2 & Blog & $\begin{array}{l}\text { Just When You } \\
\text { Thought It Was } \\
\text { Safe to Go Back in } \\
\text { the Water }\end{array}$ & $\begin{array}{l}\text { This article discusses increasing rates of endocrine disruptors, } \\
\text { intersex fish, and concern over water quality measures for } \\
\text { human consumption. }\end{array}$ \\
\hline 3 & Blog & $\begin{array}{l}\text { Letting the Rivers } \\
\text { Run: An Interview } \\
\text { With Sandra Postel }\end{array}$ & $\begin{array}{l}\text { This article discusses big dams around the world, including } \\
\text { the removal of four dams on the Klamath and the various } \\
\text { stakeholders involved in coming to a water agreement for the } \\
\text { Klamath, how dams impact ecosystems and that river flow } \\
\text { should be part of dam management, and how it is better to } \\
\text { work with nature rather than against it. }\end{array}$ \\
\hline 4 & Blog & $\begin{array}{l}\text { Rivers Can Heal - } \\
\text { When Given a } \\
\text { Chance }\end{array}$ & $\begin{array}{l}\text { This article discusses historical ecosystem aspects of the } \\
\text { Kennebec River, including the impact of a dam on fish } \\
\text { populations, and the impacts of removal of said dam in } 1997 .\end{array}$ \\
\hline 5 & Blog & $\begin{array}{l}\text { This World Water } \\
\text { Day, a Salute to the } \\
\text { Unsung Heroes of } \\
\text { Clean Water }\end{array}$ & $\begin{array}{l}\text { This article discusses mussels and how they filter and clean } \\
\text { rivers, including the biodiversity of freshwater mussels in the } \\
\text { United States and the imminent danger of losing them. }\end{array}$ \\
\hline 6 & Blog & $\begin{array}{l}\text { U.S. Great Plains, } \\
\text { Southwest at } \\
\text { extreme risk of } \\
\text { running dry, report } \\
\text { warns }\end{array}$ & $\begin{array}{l}\text { This article discusses a report on the risk to water } \\
\text { sustainability and limitation on water availability due to } \\
\text { increased demand and climate change by } 2050 \text {. The report } \\
\text { discusses the negative impacts on economic development and } \\
\text { agriculture and what locations in the U.S. are most at risk. }\end{array}$ \\
\hline 7 & Blog & $\begin{array}{l}\text { American Lifestyle } \\
\text { Costs Nearly } 2000 \\
\text { Gallons of Water } \\
\text { Each Day }\end{array}$ & $\begin{array}{l}\text { This article describes individual water footprints (including } \\
\text { emphasizing that the average American water footprint is } \\
\text { twice the global average), including indirect water usage such } \\
\text { as food and energy production. The article also mentions that } \\
\text { individual water savings is not enough and that corporations, } \\
\text { energy producers, etc. must also be part of reducing water } \\
\text { footprints. }\end{array}$ \\
\hline 8 & Blog & $\begin{array}{l}\text { Coal Ash Continues } \\
\text { to Pollute } \\
\text { Groundwater }\end{array}$ & $\begin{array}{l}\text { This article discusses the impact of coal ash, including } \\
\text { discussion on how best to regulate its disposal as it can leach } \\
\text { from landfills into groundwater. }\end{array}$ \\
\hline 9 & Blog & $\begin{array}{l}\text { Five Years After } \\
\text { Katrina, An } \\
\text { Important Lesson } \\
\text { Goes Unlearned }\end{array}$ & $\begin{array}{l}\text { This article discusses how humans impact the effects of } \\
\text { natural disasters, including how modifications to rivers and } \\
\text { floodplains inhibit natural flood protection and protection } \\
\text { from drought (ecological infrastructure) and how people } \\
\text { building in natural floodplains increases risk. }\end{array}$ \\
\hline
\end{tabular}




\begin{tabular}{|c|c|c|c|}
\hline 10 & Blog & $\begin{array}{l}\text { The Colorado River } \\
\text { IS Running Dry }\end{array}$ & $\begin{array}{l}\text { This article disputes a statement by former Secretary of the } \\
\text { Interior that the Colorado is not dealing with scarcity. } \\
\text { Although the Colorado is used greatly by water buffalos, it is } \\
\text { being overused and polluted by agriculture and other wastes, } \\
\text { changing ecosystems around it along its course. }\end{array}$ \\
\hline 11 & Blog & $\begin{array}{l}\text { Why Rivers Need to } \\
\text { Flow - High and } \\
\text { Low - Again }\end{array}$ & $\begin{array}{l}\text { This article discusses how river flow alteration is a primary } \\
\text { predictor of a river's biological integrity, and that river } \\
\text { management leading to changes in flow will change the } \\
\text { species found at the river which may impact water quality as } \\
\text { well (e.g. loss of mussels). }\end{array}$ \\
\hline 12 & Blog & $\begin{array}{l}\text { California Farmers } \\
\text { Go Deep into Water } \\
\text { Debt During } \\
\text { Drought }\end{array}$ & $\begin{array}{l}\text { This article discusses groundwater depletion from agricultural } \\
\text { irrigation, emphasizing that food security depends on future } \\
\text { access to groundwater. }\end{array}$ \\
\hline 13 & Blog & $\begin{array}{l}\text { Conservation in San } \\
\text { Antonio is Saving } \\
\text { More than Water }\end{array}$ & $\begin{array}{l}\text { This article discusses how an endangered salamander } \\
\text { prompted regulations and planning to allow San Antonio to } \\
\text { use water sustainably, with various strategies leading to } \\
\text { reduction in water usage across residential, commercial, and } \\
\text { industrial sectors. }\end{array}$ \\
\hline 14 & Blog & $\begin{array}{l}\text { Fire and Rain: The } \\
\text { One-Two Punch of } \\
\text { Flooding After } \\
\text { Blazes }\end{array}$ & $\begin{array}{l}\text { This article discusses the effects of wildfires on the magnitude } \\
\text { of flooding, including faster peak floods, property damage } \\
\text { from flooding, and the movement of sediment, boulders, and } \\
\text { trees into reservoirs. }\end{array}$ \\
\hline 15 & Blog & $\begin{array}{l}\text { Green Beer: } 4.2 \\
\text { Billion Pints (and } \\
166 \text { Billion Gallons } \\
\text { of Water) on St. } \\
\text { Paddy's Day }\end{array}$ & $\begin{array}{l}\text { This article discusses the water footprint of beer production, } \\
\text { including water usage and energy, and how many brewing } \\
\text { companies are working on sustainable growing practices to } \\
\text { lower their water and energy usage. }\end{array}$ \\
\hline 16 & Blog & $\begin{array}{l}\text { History's Wake-up } \\
\text { Call for the } \\
\text { Greenhouse Century }\end{array}$ & $\begin{array}{l}\text { This article discusses looking back across time to see the } \\
\text { impacts of prolonged water shortages in a region including } \\
\text { considering the idea of vulnerability to drought and water } \\
\text { shortages and how people's culture and settlement patterns can } \\
\text { change because of them. }\end{array}$ \\
\hline 17 & Blog & $\begin{array}{l}\text { How to "Fix" the } \\
\text { Colorado River? }\end{array}$ & $\begin{array}{l}\text { This article discusses a study that looks at the future of supply } \\
\text { and demand on the Colorado and consideration of various } \\
\text { solutions to close the gap between demand and supply, } \\
\text { including considering ecosystem health as part of looking at } \\
\text { demand. }\end{array}$ \\
\hline 18 & Blog & $\begin{array}{l}\text { Keystone XL, Clean } \\
\text { Water and } \\
\text { Democracy }\end{array}$ & $\begin{array}{l}\text { This article discusses the impact of Keystone XL, and how } \\
\text { Nebraska rallied together to keep it from being within the } \\
\text { Sandhills. Within this discussion is projected impacts if a leak } \\
\text { occurs at various points, including if it got into the Ogallala } \\
\text { Aquifer. }\end{array}$ \\
\hline
\end{tabular}




\begin{tabular}{|c|c|c|c|}
\hline 19 & Blog & $\begin{array}{l}\text { Mississippi Floods } \\
\text { Can Be Restrained } \\
\text { With Natural } \\
\text { Defenses }\end{array}$ & $\begin{array}{l}\text { This article discusses how levees are not adequate to protect } \\
\text { from flood events and that engineering fixes are not enough on } \\
\text { their own. Instead, ecological infrastructure needs to be } \\
\text { reincorporated into flood management, including expansion of } \\
\text { wetlands and re-activation of floodplains. }\end{array}$ \\
\hline 20 & Blog & $\begin{array}{l}\text { New U.S. Water } \\
\text { Rules in the Making } \\
\text { - A Once-in-a- } \\
\text { Generation } \\
\text { Opportunity to Fix } \\
\text { Past Mistakes }\end{array}$ & $\begin{array}{l}\text { This article discusses the need to put nature back into the } \\
\text { equation when discussing water planning. Consequences of } \\
\text { not including it include dead zones in the Gulf following } \\
\text { flooding of the Mississippi as fertilizers and other pollutants } \\
\text { are brought down to the Gulf. The article calls for better } \\
\text { federal rules that encourage less destructive plans that also } \\
\text { will lower risk. }\end{array}$ \\
\hline 21 & Blog & $\begin{array}{l}\text { New Voices } \\
\text { Seeking Input, More } \\
\text { Transparency in the } \\
\text { Management of the } \\
\text { Colorado River }\end{array}$ & $\begin{array}{l}\text { This article discusses emerging stakeholders in management } \\
\text { of the Colorado, including Latinos, Native tribes, and smaller } \\
\text { businesses. }\end{array}$ \\
\hline 22 & Blog & $\begin{array}{l}\text { Sandhill Cranes Are } \\
\text { Home - for Now- in } \\
\text { the Middle Rio } \\
\text { Grande }\end{array}$ & $\begin{array}{l}\text { This article discusses the positive impact of restoration work } \\
\text { within a refuge in bringing sandhill cranes back. Part of this } \\
\text { work includes managing water to create seasonal wetlands that } \\
\text { are otherwise inhibited by a dammed river. }\end{array}$ \\
\hline 23 & Blog & $\begin{array}{l}\text { Snuffbox and Rayed } \\
\text { Bean Mussels: } \\
\text { Freshwater Species } \\
\text { of the Week }\end{array}$ & $\begin{array}{l}\text { This article discusses the role of mussels in the ecosystem and } \\
\text { what their loss would mean. It also discusses the history of } \\
\text { where these two species used to occur and how their } \\
\text { distribution has diminished over time. }\end{array}$ \\
\hline 24 & Blog & $\begin{array}{l}\text { Still Wild and Free, } \\
\text { New Mexico's Gila } \\
\text { River is Again } \\
\text { Under Threat }\end{array}$ & $\begin{array}{l}\text { This article discusses how the Gila River is one of few } \\
\text { remaining undammed large rivers, but is ecologically at risk } \\
\text { from the possibility of diversion. River flows and floodplains } \\
\text { impact which species are in an area throughout the year, and } \\
\text { this diversion would negatively impact biodiversity. }\end{array}$ \\
\hline 25 & Blog & $\begin{array}{l}\text { This World Water } \\
\text { Day, Think - Energy }\end{array}$ & $\begin{array}{l}\text { This article discusses the impact of energy use on waterways, } \\
\text { and especially thermal power plants. }\end{array}$ \\
\hline 26 & Blog & $\begin{array}{l}\text { Who's Naughty and } \\
\text { Who's Nice: A Year } \\
\text { After the Everglades } \\
\text { Big Sugar Deal }\end{array}$ & $\begin{array}{l}\text { This article discusses the infrastructure built up in the } \\
\text { Everglades to try to control flooding which has led to the loss } \\
\text { of wetlands and natural floodplains, leading to degraded water } \\
\text { quality. Attempts to restore wetlands would require buying } \\
\text { out vast sugarcane properties, a pricey commodity. }\end{array}$ \\
\hline 27 & Blog & $\begin{array}{l}\text { Restoring urban } \\
\text { streams and the } \\
\text { quality of life }\end{array}$ & $\begin{array}{l}\text { This article discusses various urban stream and creek } \\
\text { restoration projects in North America and around the world, } \\
\text { including the removal of infrastructure such as parking lots to } \\
\text { allow for restoration to occur. }\end{array}$ \\
\hline 28 & Blog & $\begin{array}{l}\text { Monster Catfish } \\
\text { Found: NG's Zeb } \\
\text { Hogan Explains }\end{array}$ & $\begin{array}{l}\text { This article discusses giant blue catfish, including their } \\
\text { historical distribution and the importance of them as a food } \\
\text { source and as a resource for commercial, subsistence, and } \\
\text { recreational fisheries. }\end{array}$ \\
\hline
\end{tabular}




\begin{tabular}{|c|c|c|c|}
\hline 29 & NYT & $\begin{array}{l}\text { Pressure to Improve } \\
\text { Water Quality in } \\
\text { Chicago River }\end{array}$ & $\begin{array}{l}\text { This article discusses the critique of the method Chicago's } \\
\text { water agency took towards flooding and sewage overflow, } \\
\text { with critics indicating that the planned traditional engineering } \\
\text { solutions are not the right way to approach disinfecting the } \\
\text { water and improving river water quality. }\end{array}$ \\
\hline 30 & NYT & $\begin{array}{l}\text { The Mighty } \\
\text { Colorado at a Glide }\end{array}$ & $\begin{array}{l}\text { This article discusses paddling a stretch of the Colorado, } \\
\text { comparing and contrasting it to paddling through the Grand } \\
\text { Canyon. }\end{array}$ \\
\hline 31 & NYT & $\begin{array}{l}\text { With Fears of Asian } \\
\text { Carp Fading, a } \\
\text { Sleek Campaign to } \\
\text { Revive Public } \\
\text { Concern }\end{array}$ & $\begin{array}{l}\text { This article discusses the fight against Asian Carp in the Great } \\
\text { Lakes, including how different groups suggest different } \\
\text { solutions. It also notes that the public is losing concern over } \\
\text { the issue. }\end{array}$ \\
\hline 32 & NYT & $\begin{array}{l}\text { A Mining Law } \\
\text { Whose Time Has } \\
\text { Passed }\end{array}$ & $\begin{array}{l}\text { This article critiques current mining law that gives hard-rock } \\
\text { mining precedence over other uses of federal land. Mining } \\
\text { companies are supposed to protect rivers threatened by their } \\
\text { operations, but do not have a good track history in doing so. } \\
\text { The article calls for changing the law in order to "provide } \\
\text { safeguards for clean water and give communities and agencies } \\
\text { a say about where mining is permitted." }\end{array}$ \\
\hline 33 & NYT & $\begin{array}{l}\text { That's No Water } \\
\text { Hazard. It's a 'Poor } \\
\text { Man's Golf Range' }\end{array}$ & $\begin{array}{l}\text { This article discusses a "poor man's golf range" where } \\
\text { individuals from a poorer neighborhood hit salvaged golf balls } \\
\text { into the Harlem River. }\end{array}$ \\
\hline 34 & NYT & $\begin{array}{l}\text { E.P.A. Steps Up } \\
\text { Scrutiny of } \\
\text { Pollution in } \\
\text { Pennsylvania Rivers }\end{array}$ & $\begin{array}{l}\text { This article discusses the impact of drilling waste on drinking } \\
\text { water, including discussion of the importance of location of } \\
\text { water quality monitoring sites and the need to test for } \\
\text { radioactivity in addition to other contaminants. }\end{array}$ \\
\hline 35 & NYT & $\begin{array}{l}\text { Wrong Answer at } \\
\text { Indian Point }\end{array}$ & $\begin{array}{l}\text { This article discusses the concern over water quality related to } \\
\text { Indian Point nuclear power plant. The energy company wants } \\
\text { to implement untested changes to try to lower the number of } \\
\text { fish killed, while the government wants them to implement a } \\
\text { different cooling system. }\end{array}$ \\
\hline 36 & NYT & $\begin{array}{l}\text { Who Controls } \\
\text { Montana's Rivers? }\end{array}$ & $\begin{array}{l}\text { This article discusses Montana wanting an assessment of } \\
\text { whether a waterway was navigable at statehood, and thus } \\
\text { controlled by the State of Montana (rather than the federal } \\
\text { government). If so, the state stands to collect } \$ 50 \text { million from } \\
\text { a power company licensed by the federal government. }\end{array}$ \\
\hline 37 & NYT & $\begin{array}{l}\text { Along a Course Of } \\
\text { Purling Rivers, A } \\
\text { Raw Divide }\end{array}$ & $\begin{array}{l}\text { This article discusses the possibility of megaloads being } \\
\text { transported along the Blackfoot River, to move oil-processing } \\
\text { equipment from Idaho into Canada. Critics worry the loads } \\
\text { will change the wild character of the river (along with general } \\
\text { concerns over how the transport will alter transportation along } \\
\text { the roadways). }\end{array}$ \\
\hline 38 & NYT & $\begin{array}{l}\text { E.P.A. Issues Rules } \\
\text { to Limit Water } \\
\text { Pollution From }\end{array}$ & $\begin{array}{l}\text { This article discusses new guidelines on mining, including } \\
\text { permissible levels of mining runoff introduced into waterways } \\
\text { surrounding a project. These regulations would make }\end{array}$ \\
\hline
\end{tabular}




\begin{tabular}{|c|c|c|c|}
\hline & & Mining & $\begin{array}{l}\text { obtaining a permit more difficult for certain types of } \\
\text { operations. }\end{array}$ \\
\hline 39 & NYT & $\begin{array}{l}\text { Los Angeles River } \\
\text { Tries On an } \\
\text { Unaccustomed } \\
\text { Role, as a Waterway }\end{array}$ & $\begin{array}{l}\text { This article discusses a pilot project to allow and encourage } \\
\text { paddling of the Los Angeles River. }\end{array}$ \\
\hline 40 & NYT & $\begin{array}{l}\text { A Mountain in the } \\
\text { Stream }\end{array}$ & $\begin{array}{l}\text { This article discusses changes in presidential administration } \\
\text { impacting the effectiveness of regulators of the Clean Water } \\
\text { Act. Under the Obama administratrion, scientific analysis of } \\
\text { proposed downstream impacts from a mine would be required } \\
\text { before receiving a permit. The article provides an example of a } \\
\text { mine in West Virginia whose permit may be vetoed due to its } \\
\text { likely damage to streams and wildlife. }\end{array}$ \\
\hline 41 & NYT & $\begin{array}{l}\text { How Hot Is } 104 ? \\
\text { New York Counts } \\
\text { the Miseries }\end{array}$ & $\begin{array}{l}\text { This article discusses a heat wave and the lack of water } \\
\text { recreation available to the public due to a fire at a sewage } \\
\text { plant that led to untreated sewage being dumped into rivers. }\end{array}$ \\
\hline 42 & NYT & $\begin{array}{l}\text { Reclaimed Jewel } \\
\text { Whose Attraction } \\
\text { Can Be Perilous }\end{array}$ & $\begin{array}{l}\text { This article discusses the history of the Bronx River, including } \\
\text { the restoration activities in the recent past that bring more of } \\
\text { the public down to the river. A result of the restoration is the } \\
\text { return of visible wildlife. }\end{array}$ \\
\hline 43 & NYT & Rising Waters & $\begin{array}{l}\text { This article discusses preparation for flooding in Fremont } \\
\text { County, Wyoming, as locals are aware of what is coming due } \\
\text { to melting snow as the weather warms up. }\end{array}$ \\
\hline 44 & NYT & $\begin{array}{l}\text { Give Thanks for . } \\
\text { Eel? }\end{array}$ & $\begin{array}{l}\text { This article discusses the history of eels in Eastern rivers and } \\
\text { how global markets are impacting eel populations. In } \\
\text { addition, local wetlands and waterways should be restored or } \\
\text { modified (e.g. dams) to allow for better conditions for eels. }\end{array}$ \\
\hline 45 & NYT & $\begin{array}{l}\text { After a Blaze, } \\
\text { Waste Floods The } \\
\text { Hudson }\end{array}$ & $\begin{array}{l}\text { This article discusses a fire at a sewage treatment plant, } \\
\text { leading to dumping of untreated sewage into the Hudson and } \\
\text { Harlem Rivers, making them unsafe for water recreation. }\end{array}$ \\
\hline 46 & NYT & $\begin{array}{l}\text { Carp Invasion May } \\
\text { Prompt Changes to } \\
\text { Waterways }\end{array}$ & $\begin{array}{l}\text { This article discusses waterway locks to prevent Asian Carp } \\
\text { from entering the Great Lakes. }\end{array}$ \\
\hline 47 & NYT & $\begin{array}{l}\text { Another Christo } \\
\text { Project, To Engage } \\
\text { and Divide }\end{array}$ & $\begin{array}{l}\text { This article discusses concerns over an art project by Christo } \\
\text { over the Arkansas River in Colorado, including whether it } \\
\text { would provide an economic boom to the local community. }\end{array}$ \\
\hline 48 & NYT & Rivers Less Paddled & $\begin{array}{l}\text { This article provides seven less-trafficked areas for paddling } \\
\text { as suggested by kayaking experts. }\end{array}$ \\
\hline 49 & NYT & $\begin{array}{l}\text { The River } \\
\text { Untamable }\end{array}$ & $\begin{array}{l}\text { This article discusses the flooding of the Mississippi, } \\
\text { including how humans have modified the river and moved too } \\
\text { close to it, increasing their risks. }\end{array}$ \\
\hline 50 & NYT & $\begin{array}{l}\text { Sewage Frequently } \\
\text { Fouls Hudson } \\
\text { River, Report Says }\end{array}$ & $\begin{array}{l}\text { This article discusses a Riverkeeper water quality testing } \\
\text { program on the Hudson River, with } 21 \% \text { of samples having } \\
\text { unacceptable levels of bacteria. The group wants better public } \\
\text { notification as more people interact with the Hudson. }\end{array}$ \\
\hline
\end{tabular}




\begin{tabular}{|c|c|c|c|}
\hline 51 & NYT & $\begin{array}{l}\text { After Devastating } \\
\text { Floods, Debate } \\
\text { Over Mission Of the } \\
\text { Missouri Rolls On }\end{array}$ & $\begin{array}{l}\text { This article discusses inter-state negotations on how to manage } \\
\text { the Missouri, including whether navigation or recreation } \\
\text { should be a priority and how these priorities impact flood } \\
\text { management. }\end{array}$ \\
\hline 52 & NYT & $\begin{array}{l}\text { Rulings Restrict } \\
\text { Clean Water Act, } \\
\text { Hampering E.P.A. }\end{array}$ & $\begin{array}{l}\text { This article discusses loopholes in the Clean Water Act that } \\
\text { allow polluters to go unregulated. Certain waterways deemed } \\
\text { not navigable (which may include wetlands or seasonal } \\
\text { streams) may not be protected. There are also questions over } \\
\text { whether state or federal jurisdiction applies and thus who can } \\
\text { prosecute. }\end{array}$ \\
\hline 53 & NYT & $\begin{array}{l}\text { Levee Breach } \\
\text { Moves One Step } \\
\text { Closer }\end{array}$ & $\begin{array}{l}\text { This article discusses the decisionmaking process on deciding } \\
\text { whether to blow up a levee to protect the town of Cairo, } \\
\text { Illinois. Blowing up the levee would innundate farmland in } \\
\text { Missouri. }\end{array}$ \\
\hline 54 & NYT & $\begin{array}{l}\text { Athletes With a } \\
\text { Rope to Hold, and } \\
\text { Water to Stand On }\end{array}$ & $\begin{array}{l}\text { This article discusses a waterskiing troupe that performs for } \\
\text { free on the Mohawk River. }\end{array}$ \\
\hline 55 & NYT & $\begin{array}{l}\text { A Sneaky Attack on } \\
\text { Clean Water Rules }\end{array}$ & $\begin{array}{l}\text { This article discusses how new guidelines of the Clean Water } \\
\text { Act become completely ineffective as the House } \\
\text { Appropriations Committee included language in the Army } \\
\text { Corps of Engineers spending bill that inhibits them from } \\
\text { spending any money to do anything with the new guidelines. }\end{array}$ \\
\hline 56 & NYT & $\begin{array}{l}\text { In Mississippi } \\
\text { Delta, All Eyes on a } \\
\text { Swelling River }\end{array}$ & $\begin{array}{l}\text { This article discusses flooding of the Mississippi and } \\
\text { preparations made in Memphis in anticipation of localized } \\
\text { flooding. Other flooded areas, including the White River in } \\
\text { Arkansas, are also discussed. }\end{array}$ \\
\hline 57 & NYT & $\begin{array}{l}\text { An Oil Spill Grows } \\
\text { in Brooklyn }\end{array}$ & $\begin{array}{l}\text { This article discusses a history of neglectful regulators who } \\
\text { allowed oil companies to poision a local creek, making it unfit } \\
\text { for drinking water. This long-standing spill contains } 17 \text { to } 30 \\
\text { million gallons of contaminants. }\end{array}$ \\
\hline 58 & NYT & $\begin{array}{l}\text { U.S. Clears Art } \\
\text { Project By Christo } \\
\text { In Colorado }\end{array}$ & $\begin{array}{l}\text { This article discusses that federal permits were granted for } \\
\text { Christo's art installation over the Arkansas River in Colorado, } \\
\text { including provisions to protect local bighorn sheep. State and } \\
\text { local permits were still needed at the time. }\end{array}$ \\
\hline 59 & NYT & $\begin{array}{l}\text { Where Water Is an } \\
\text { Old Friend, Until It } \\
\text { Turns Into a } \\
\text { Nemesis }\end{array}$ & $\begin{array}{l}\text { This article discusses the impacts of opening of a spillway due } \\
\text { to flooding of the Mississippi on the Atchafalaya Basin in } \\
\text { Louisiana. It discusses the possible negative impacts on cajun } \\
\text { country where multiple generations have lived. }\end{array}$ \\
\hline 60 & NYT & $\begin{array}{l}\text { Hudson River and } 4 \\
\text { Beaches Are } \\
\text { Deemed to Be Safe } \\
\text { Again }\end{array}$ & $\begin{array}{l}\text { This article discusses reopening of waterways following a } \\
\text { sewage contamination due to a treatment plant fire. It includes } \\
\text { economic impacts of the closure on businesses, including } \\
\text { camps and kayak rental companies. }\end{array}$ \\
\hline 61 & NYT & $\begin{array}{l}\text { Anxious Eyes on a } \\
\text { River As Flooding } \\
\text { Threat Looms }\end{array}$ & $\begin{array}{l}\text { This article discusses the possibility of blowing up a levee to } \\
\text { protect a small town ( } 3,000 \text { people) in Illinois. Doing so } \\
\text { would flood farmland, in turn home to about } 200 \text { residents. }\end{array}$ \\
\hline
\end{tabular}




\begin{tabular}{|c|c|c|c|}
\hline 62 & NYT & $\begin{array}{l}\text { Chemicals in Farm } \\
\text { Runoff Rattle States } \\
\text { on the Mississippi }\end{array}$ & $\begin{array}{l}\text { This article discusses potential regulatory action, long term } \\
\text { problems, and solutions to combat dead zones in the Gulf zone } \\
\text { caused by farming upstream of the Mississippi. }\end{array}$ \\
\hline 63 & NYT & $\begin{array}{l}\text { Mississippi River } \\
\text { Crowds Memphis }\end{array}$ & $\begin{array}{l}\text { This article discusses concern over flooding of the Mississippi } \\
\text { in Memphis, including people viewing it as a spectacle while } \\
\text { others dealt with evacuation. }\end{array}$ \\
\hline 64 & NYT & $\begin{array}{l}\text { Signs of an Urban } \\
\text { River's Revival in } \\
\text { Virginia }\end{array}$ & $\begin{array}{l}\text { This article discusses the cleanup and restoration of the James } \\
\text { River in Richmond, VA, including how people and wildlife } \\
\text { are now using the river. }\end{array}$ \\
\hline 65 & NYT & $\begin{array}{l}\text { Fly Fishers Serving } \\
\text { as Transports for } \\
\text { Noxious Little } \\
\text { Invaders }\end{array}$ & $\begin{array}{l}\text { This article discusses fly fishermen shoes transporting didymo } \\
\text { (an algae). This algae can "choke out" insect life and impact } \\
\text { fish populations. }\end{array}$ \\
\hline 66 & NYT & $\begin{array}{l}\text { Latest Dirty Water } \\
\text { Bill }\end{array}$ & $\begin{array}{l}\text { This article criticizes Repbulicans by saying they are trying to } \\
\text { subvert the Clean Water Act by removing protection from } \\
\text { small streams and wetlands. }\end{array}$ \\
\hline 67 & NYT & $\begin{array}{l}520 \text { Miles of } \\
\text { Waterfront To Get } \\
\text { Long-Range Plan }\end{array}$ & $\begin{array}{l}\text { This article discusses a long-term plan in New York City to } \\
\text { consolidate proposed or underway waterfront projects rather } \\
\text { than have them each be considered individually. The plan } \\
\text { would not cost more money, but would protect specific } \\
\text { projects if there is future cost-cutting since they would be } \\
\text { consolidated. }\end{array}$ \\
\hline 68 & NYT & $\begin{array}{l}\text { Spread Forth In the } \\
\text { Shadow Of the } \\
\text { Mountains }\end{array}$ & $\begin{array}{l}\text { This article discusses visiting the Owens Valley and Owens } \\
\text { River Gorge in eastern California. It also discusses the Los } \\
\text { Angeles Department of Water and Power's ownership of land } \\
\text { in the area used for the city's water supply, how the City } \\
\text { allows access, and how it manages water in the Owens River. }\end{array}$ \\
\hline 69 & WSJ & $\begin{array}{l}\text { DESTINATIONS; } \\
\text { Southern Charms; A } \\
\text { steady stream of } \\
\text { retirees are finding } \\
\text { their way to } \\
\text { Charleston and } \\
\text { South Carolina's } \\
\text { Lowcountry }\end{array}$ & $\begin{array}{l}\text { This article discusses Charleston, SC and how it is "a mix of } \\
\text { cultural offerings, entertainment, history and natural beauty" } \\
\text { by being a pedestrian-friendly waterfront. }\end{array}$ \\
\hline 70 & WSJ & $\begin{array}{l}\text { Waterways Locked } \\
\text { in a Quandary; The } \\
\text { Obama } \\
\text { administration } \\
\text { wants to boost the } \\
\text { use of waterways to } \\
\text { haul freight, but the } \\
\text { government first } \\
\text { needs to upgrade the } \\
\text { nation's } \\
\text { underfunded and }\end{array}$ & $\begin{array}{l}\text { This article uses the Charleroi Locks of the Monongahela } \\
\text { River in Pennsylvania as an example of old, under-maintained } \\
\text { locks and how this impacts the shipping industry. }\end{array}$ \\
\hline
\end{tabular}




\begin{tabular}{|c|c|c|c|}
\hline & & $\begin{array}{l}\text { decrepit locks and } \\
\text { dams }\end{array}$ & \\
\hline 71 & WSJ & $\begin{array}{l}\text { Christo vs. } \\
\text { Colorado }\end{array}$ & $\begin{array}{l}\text { This article discusses the controversy over Christo's potential } \\
\text { art installation over the Arkansas River in Colorado, including } \\
\text { battling locals and dealing with environmental impact } \\
\text { statements. }\end{array}$ \\
\hline 72 & WSJ & $\begin{array}{l}\text { Heard \& Scene -- } \\
\text { Donor of the Day: } \\
\text { Helping Protect the } \\
\text { Hudson River }\end{array}$ & $\begin{array}{l}\text { This article discusses a hedge fund management company } \\
\text { founder/CEO donating money to Riverkeeper in support of } \\
\text { their work to prevent the relicensing of the Indian Point } \\
\text { nuclear power plant in Buchanan, NY. }\end{array}$ \\
\hline 73 & WSJ & $\begin{array}{l}\text { City News -- Urban } \\
\text { Gardner: One Sunny } \\
\text { Side of Sewage }\end{array}$ & $\begin{array}{l}\text { This article discusses a photographer who has documented } \\
\text { Newtown Creek in New York City prior to its designation as a } \\
\text { Superfund site. }\end{array}$ \\
\hline 74 & WSJ & $\begin{array}{l}\text { Heavy Rains Keep } \\
\text { Levee-Blast Plans } \\
\text { on Track }\end{array}$ & $\begin{array}{l}\text { This article discusses the possibility of blowing up a levee to } \\
\text { protect the town of Cairo, Illinois from being inundated with } \\
18 \text { to } 20 \text { feet of flood water. }\end{array}$ \\
\hline 75 & WSJ & $\begin{array}{l}\text { Amid carp threat, a } \\
\text { call to unhook; } \\
\text { Great Lakes states } \\
\text { want to undo a } \\
\text { historic project and } \\
\text { disconnect from the } \\
\text { Mississippi to fend } \\
\text { off invasive fish }\end{array}$ & $\begin{array}{l}\text { This article discusses a call to disconnect the Great Lakes from } \\
\text { the Mississippi to protect them from invasive Asian Carp. The } \\
\text { shipping industry wants to allow for navigational locks to keep } \\
\text { from destroying industry in the region, and look for alternative } \\
\text { solutions to prevent the Carp from invading. }\end{array}$ \\
\hline 76 & WSJ & $\begin{array}{l}\text { When Death Is } \\
\text { Merely a Paddle } \\
\text { Stroke Away }\end{array}$ & $\begin{array}{l}\text { This article discusses personal experience of learning to } \\
\text { whitewater kayak, providing examples from the Salmon River } \\
\text { in Humboldt County, CA. }\end{array}$ \\
\hline
\end{tabular}

